Canadian

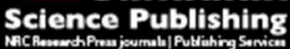

Environmental Reviews Dossiers environnement

\title{
Biomonitoring of metals and metalloids with raptors from Portugal and Spain: a review
}

\begin{tabular}{|r|l|}
\hline Journal: & Environmental Reviews \\
\hline Manuscript ID & er-2015-0051.R1 \\
\hline Manuscript Type: & Review \\
\hline Date Submitted by the Author: & $20-$ Oct-2015 \\
\hline Complete List of Authors: & $\begin{array}{l}\text { Carneiro, Manuela Andreia; University of Trás-os-Montes e Alto Douro, } \\
\text { Veterinary Sciences } \\
\text { Colaço, Bruno; University of Trás-os-Montes e Alto Douro, Zootechnics } \\
\text { Colaço, Jorge; University of Trás-os-Montes e Alto Douro, Zootechnics } \\
\text { Faustino-Rocha, Ana; University of Trás-os-Montes e Alto Douro, } \\
\text { Veterinary Sciences } \\
\text { Colaço, Aura; University of Trás-os-Montes e Alto Douro, Veterinary } \\
\text { Sciences } \\
\text { Lavín, Santiago; Autonomous University of Barcelona, Medicine and Animal } \\
\text { Surgery } \\
\text { Oliveira, Paula Alexandra; University of Trás-os-Montes e Alto Douro, } \\
\text { Veterinary Sciences }\end{array}$ \\
\hline \multirow{2}{*}{ Keyword: } & $\begin{array}{l}\text { environmental contamination, metals, raptors, Iberian Peninsula, } \\
\text { biomonitoring }\end{array}$ \\
\hline \hline
\end{tabular}




\title{
BIOMONITORING OF METALS AND METALLOIDS WITH
}

\section{RAPTORS FROM PORTUGAL AND SPAIN: A REVIEW}

\author{
Carneiro Manuela $^{\text {a,b }}$, Colaço Bruno ${ }^{\text {a,c }}$, Colaço Jorge ${ }^{c}$, Faustino-Rocha Ana I. ${ }^{\text {a,b }}$, \\ Colaço Aura ${ }^{\mathrm{b}}$, Lavin Santiago ${ }^{\mathrm{d}}$, Oliveira Paula A. ${ }^{\mathrm{a}, \mathrm{b}^{*}}$
}

a Centre for the Research and Technology of Agro-Environmental and Biological Sciences (CITAB), University of Trás-os-Montes e Alto Douro (UTAD), Vila Real, Portugal.

${ }^{b}$ Department of Veterinary Sciences, School of Agrarian and Veterinary Sciences (ECAV), University of Trás-os-Montes e Alto Douro (UTAD), Vila Real, Portugal.

${ }^{c}$ Department of Zootechnics, ECAV (School of Agrarian and Veterinary Sciences), University of Trás-os-Montes e Alto Douro, Vila Real, Portugal.

d Servei d'Ecopatologia de Fauna Salvatge (SEFaS), Department of Medicine and Animal Surgery, Autonomous University of Barcelona, Bellaterra, Spain.

* Corresponding author at:

Paula A. Oliveira

Department of Veterinary Sciences, ECAV

University of Trás-os-Montes e Alto Douro

Quinta dos Prados

5000-801,Vila Real,

Portugal

E-mail:pamo@utad.pt

Fax: 00351259250480

Phone number: 00351259350651

Word count: 6667 (without title, abstract, keywords, references and tables) 


\title{
BIOMONITORING OF METALS AND METALLOIDS WITH
}

\section{RAPTORS FROM PORTUGAL AND SPAIN: A REVIEW}

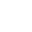

\begin{abstract}
The analysis of metals in different tissues of raptors has been an important tool for assessing metal pollution. Several studies using a range of sentinel raptor species have been carried out in Portugal and Spain since the 1980s in order to identify the adverse effects in the animals themselves and on their populations, to identify the contamination of the food-chain, to determine the levels of environmental contamination and to estimate human health risks.
\end{abstract}

The aim of this work is to provide synthesized information of the studies carried out in Portugal and Spain in the direct biomonitoring of metals and metalloids using raptors, through a systematic search of the published literature. The information is summarized taking into account specific issues such as monitored raptor species, sampling periods, monitored areas, type of samples, analytical techniques used in the determination of the metals and metalloids, the analysed metals and metalloids and overall analysis of the concentrations obtained.

There is a striking difference between the number of studies performed in Portugal and Spain, and most of them have been carried out in Spain. The Eagle owl, Black kite and Common buzzard were the species from which the greatest number of individuals has been analysed. Among the most analyzed biological samples, the blood and liver samples were used to measure the concentrations of all studied metals, while bone was mainly collected to evaluate chronic exposure to lead and feathers to evaluate exposure to mercury during feather growth. Atomic Absorption Spectrometry has been the most frequently performed technique to determine the majority of metals and arsenic. In general, the concentrations of metals detected in raptor samples from Portugal and Spain are low and insufficient to produce toxic side effects. Only lead, in certain cases, can be related with toxic side effects. However, it 
25 should be given particular attention to mercury due to its high toxicity, its transport from an 26 aquatic environment to the adjacent terrestrial food web and because mercury toxicity 27 threshold have yet to be established for raptors. This work confirms the need for further biomonitoring studies of metals with raptors, especially in Portugal; the establishing of national programs in order to conduct long-term studies; and creating a network between Portugal and Spain in order to study environmental contamination using raptors.

32

Keywords: biomonitoring, environmental contamination, metals, raptors, Portugal, 35 Spain. 


\section{Introduction}

37 Metals are natural constituents of all ecosystems that are present at low concentrations 38 in soils, plants and living organisms. Their distribution in the environment results from 39 natural processes and various anthropogenic activities. However, human activities 40 significantly increase their presence in the environment and in many ecosystems these 41 anthropogenic inputs exceed removals by natural biogeochemical cycles of metals 42 (Pacyna and Pacyna 2001; Florea and Busselberg 2006).

43 Some metals, such as copper $(\mathrm{Cu})$, cobalt $(\mathrm{Co})$, iron $(\mathrm{Fe})$, molybdenum $(\mathrm{Mo})$, 44 manganese $(\mathrm{Mn})$, selenium $(\mathrm{Se})$ and zinc $(\mathrm{Zn})$ are considered important micronutrients 45 since they are required in relatively small amounts for many physiological processes in 46 living beings. If their supply is below physiological requirements it can result in 47 deficiency diseases, but in larger amounts they may be harmful and even toxic to 48 organisms. Other metals such as $\mathrm{Cd}, \mathrm{Pb}$ and $\mathrm{Hg}$ are not necessary for any physiological 49 processes, they have toxic effects on living organisms and are classified as contaminants 50 or non-essential elements (Ernst et al. 1983; He et al. 2005; Florea and Busselberg 2006).

51 These are the most dangerous metals for both humans and animals, not only because of 52 their high toxicity but also due to their persistence and pronounced biological 53 accumulation and biomagnification in food chains (Burger 1995, 2008; García-Fernández 54 et al. 1996; Cristol et al. 2008). As is a metalloid or a semi-metal, and although there is 55 some uncertainty regarding its necessity for physiological processes, it is well known that 56 it has toxic effects on living beings (Uthus 1992; Eisler 1998; Shi et al. 2004; Hughes 57 2006). Unlike other toxic metals, As has a low rate of bioaccumulation and it is not 58 biomagnified in the food chain (Eisler 1998; Hughes 2006). 
59 Environmental contamination by non-essential elements is a worldwide problem and 60 represents a serious threat to the stability of ecosystems and living organisms (Barbosa et 61 al. 2014). The need to determine the degree of exposure and the effects of contaminants 62 in both animals and humans has led to numerous biomonitoring studies. Direct 63 monitoring of air, soil, water and sediments can be useful to determine the degree of 64 contamination in a particular area; however, it does not provide a measure of 65 bioavailability and resultant uptake by biota or people. It is only through direct 66 biomonitoring (the analysis of contaminants in fluids and tissues of organisms) that the 67 actual exposure of organisms can be properly determined and related to the levels in the 68 physical environment (Beeby 2001; Gómez-Ramírez et al. 2014). In general, the 69 objectives of monitoring sentinel animals include data collection in order to: (1) estimate 70 human health risks; (2) identify contamination of the food-chain; (3) determine the levels 71 of environmental contamination; (4) identify adverse effects on animals; (5) examine 72 spatial or temporal trends in contamination levels (National Research Council (US) 1991; 73 Gómez-Ramírez et al. 2014).

74 Many of these studies are carried out with birds, which are particularly sensitive to 75 anthropogenic contamination (Anthony et al. 1993; Dauwe et al. 2000; Battaglia et al. 76 2005; Alleva et al. 2006; Burger and Gochfeld 2009; Naccari et al. 2009; Alvárez et al. 77 2013). Amongst birds, raptors (birds of prey, owls and scavengers) are considered 78 especially suitable for monitoring bioaccumulable and biomagnificable pollutants, mainly 79 due to their position at the top of trophic chain (Furness 1993). They may also provide 80 information about the integration of contaminants that reach other species at the top of 81 trophic chain, such as humans (Furness 1993; Zolfaghari et al. 2007; Figueira et al. 82 2009). Other key characteristics make raptors good sentinels for environmental 
83 contamination, namely their relatively large home range; relative ease with which

84 individuals (particularly nestlings) can be captured and non-destructive samples (blood,

85 feather, preen gland oil) can be collected; and relative ease with which populations can be

86 quantified and monitored (Becker 2003; Gómez-Ramírez et al. 2014). Moreover, raptors

87 are known to have measurable responses to persistent, bioaccumulative and toxic

88 chemicals, ranging from residue accumulation to population decline (Newton et al. 1993;

89 Mateo et al. 1997b; Berglund et al. 2007; Gangoso et al. 2009; Lee et al. 2012; Espín et

90 al. 2014a).

91 Portugal and Spain are rich in bird life, holding breeding populations of 34 species of

92 raptors from 56 species that breed regularly in Europe (Table 1). These countries are also

93 home to important populations of several threatened species at an European level, such as

94 Spanish Imperial eagle (Aquila adalberti), Red kite (Milvus milvus), Bonelli's eagle

95 (Hieraaetus fasciatus), Egyptian vulture (Neophron percnopterus), Cinereous vulture

96 (Aegypius monachus) and Bearded vulture (Gypaetus barbatus) (Burfield 2008).

97 Moreover, Spain is home to more than $95 \%$ of all European avian scavengers and the

98 world's entire Spanish imperial eagle population (Margalida 2012). Given the important

99 ecological role (providing important ecosystems) of the raptor species, their high profile

100 and popularity with the public health, the political commitment to halt biodiversity loss in

101 Europe and the implications that toxic metals could have on their conservation, it is

102 timely to review the studies directed towards the monitoring of toxic metals using raptors

103 from Portugal and Spain as biomonitors.

104 The aim of this work is to provide synthesized information of the studies carried out in

105 Portugal and Spain on the biomonitoring of metals and metalloids using raptors, through

106 a systematic search of the published literature. Taking into consideration only the studies 
107 that performed direct biomonitoring, the information is summarized taking in account the

108 following specific issues: monitored raptor species, sampling periods, monitored areas, 109 type of samples, the analytical techniques used in the determination of the metals, the analysed metals and metalloids, and the concentrations obtained.

\subsection{Monitored raptors species}

Raptor species have been an important group of species used for monitoring purposes, not only because many of them are excellent sentinels of environmental contamination indicating specific environmental change, but also because they are valued natural resources in their own right with an important ecological role (providing important cultural and regulatory ecosystem), that may be adversely affected by toxicant exposure (Becker 2003; Golden and Rattner 2003). Due to the conservation problems associated with pollutant exposure and accumulation in some endangered raptor species in Europe (BirdLife International, 2004), raptors in general, and endangered species in particular, should be studied as a priority.

122 In table 1 are summarized the main characteristics (trophic position and the most important prey, conservation status and migratory habits) of the raptor species breeding in

124 Portugal and Spain, specifying which ones were used for monitoring purposes of metals and the total number of analysed individuals. The selection of the raptor species for monitoring metals and metalloids has been mainly influenced by the availability of

127 samples, which in turn is conditioned by particular features of each species, such as abundance and conservation status, geographical distribution, type of habitat and migration habits. For example, the collection of samples from animals in their natural environment can sometimes be difficult to accomplish in raptors from wooded or 
131 mountainous areas, especially out of the breeding season, and the cost and inherent

132 difficulty in obtaining samples are also disadvantages (García-Fernández et al. 2008).

133 Collaboration with Wildlife Rehabilitation Centres (WRCs) can be useful for

134 environmental biomonitoring, mainly when it is difficult to collect samples from animals

135 in their natural environment, as it was in the sample collection of the Common buzzard

136 (Buteo buteo), one of the most commonly used species in biomonitoring studies in both

137 countries (García-Fernández et al. 1995, 1996, 1997; Mateo et al. 2003; Pérez-López et

138 al. 2008; Castro et al. 2011; Carneiro et al. 2014).

139 The type of diet has also been an important factor in the selection of the bird species,

140 since it influences the bioaccumulation of metals (García-Fernández et al. 1995; Palma et

141 al. 2005). García-Fernández et al. (1995) and Mateo et al. (2003) found the highest Pb

142 concentrations in tissues of bird species that usually feed on carrion, and the piscivorous

143 species are capable of accumulating higher concentrations of $\mathrm{Hg}$ in their tissues

144 (Thompson 1996; Evers et al. 2005). Most of the species frequently monitored in

145 Portugal and Spain are mixed feeders, often taking a mixture of mammalian, avian, fish

146 and, in some cases, invertebrate prey, which is considered by some authors a suitable

147 characteristic in biomonitoring studies of different contaminants (Battaglia et al. 2005).

148 However, diet variation may have major confounding effects in studies on biomonitoring

149 environmental contamination using birds of prey. Furthermore, due to the capacity of

150 some species to exploit a wide variety of food resources and consequently its diet

151 depends on the availability of optimal and suboptimal prey species, pollutant uptake and

152 accumulation can be highly variable among different territories and periods depending on

153 the diet composition (Mañosa et al. 2003; Ortiz-Santaliestra et al. 2015). 
154

155

156

157

158

159

160

161

162

163

164

165

166

167

168

169

170

171

172

For this reason, some authors recommended the use of bird species with narrow and inflexible diets in contamination studies, rather than generalist predators (Monteiro and Furness 1995; Palma et al. 2005; Hollamby et al. 2006). However, true dietary specialists are hard to find and constant diets across space and time are unwarranted.

The aim of the work is also a determining factor in the selection of the biomonitor bird species. For example, species that have an unfavourable conservation status, such as the Bearded vulture, Egyptian vulture and Spanish imperial eagle were used in research studies that mainly aimed to assess the adverse effects of metals on their populations (González and Hiraldo 1988; Hernández et al. 1988a; Donázar et al. 2002; Pain et al. 2005; Hernández and Margalida 2009; Rodriguez-Ramos et al. 2011).

Most of the raptor species breeding in Portugal and Spain have been used at some stage for monitoring metals. However, in many cases, the number of analysed specimens was very low, being fewer than 20 (Cinereous vulture, Golden eagle Aquila chrysaetos, Short-toed eagle Circaetus gallicus, Montagu’s harrier Circus pygargus, Hobby Falco subbuteo, Peregrine falcon Falco peregrinus, Long-eared owl Asio otus and Scops owl Otus scops). Amongst the monitored raptors, Eagle owl (Bubo bubo) (n=979), Black kite (Milvus migrans) $(\mathrm{n}=428)$ and Common buzzard $(\mathrm{n}=428)$ are the species from which the greatest number of individuals has been analysed. The Spanish imperial eagle is found only in the Iberian Peninsula and it is considered one of the most threatened birds of prey in Europe (González et al. 2008). Several studies have analysed the risk of metals for the conservation of this species in a relatively large number of individuals $(n=257)$. In Portugal, only the raptor species Common buzzard, Griffon vulture (Gyps fulvus), Eagle owl, Bonelli's eagle (Hieraaetus fasciatus), Little owl (Athene noctua), Tawny owl (Strix aluco) and Barn owl (Tyto alba) were used for monitoring purposes, wherein were 
178 sampled less than 20 individuals in the last three referred species (Palma et al. 2005;

179 Figueira et al. 2009; Lourenço et al. 2011; Carneiro et al. 2014, 2015). Eagle owl and

180 Common buzzard gather relevant features, such as favourable conservation status, wide 181 geographical distribution, non-migratory habits, and high territoriality and diversified

182 diet, which make them suitable biomonitors. Although the Black kite is a migratory bird, 183 its other life history traits make it also a suitable species for contaminants monitoring. 184 They often breed in habitats that are highly affected by agricultural, industrial and urban 185 pollution. Therefore, they were important indicators of environmental contamination in 186 an environmental disaster (Aznalcóllar mining accident) and in polluted areas (Benito et 187 al. 1999; Blanco et al. 2003; Baos et al. 2006a, 2006b; Alvárez et al. 2013). Furthermore, 188 some studies have shown that Black kites are susceptible to metal toxicity and 189 contamination has been suspected as an important factor that contributes to the decline of 190 their populations. In general, the least sampled species for metal-monitoring purposes are 191 those with an unfavourable conservation status and/or with migratory habits.

192 In future studies, other raptor species such as the Eurasian sparrowhawk (Accipiter 193 nisus), Common kestrel (Falco tinnunculus), Little owl, Tawny owl and Barn owl can be used more frequently for biomonitoring purposes of metals, since they have the characteristics essential to be suitable biomonitors, namely their relative high abundance that can easily provide a large number of samples for environmental biomonitoring. 197 Future efforts should also be focused on the study of those species that have 198 demonstrated their usefulness in matters of conservation, such as the Black-winged kite 199 (Elanus caeruleus), Bonelli’s eagle, Cinereous vulture, Egyptian vulture, Golden eagle, 200 Red kite and Osprey (Pandion haliaetus). 


\subsection{Sampling periods and monitored areas}

In table 2 are listed the sampling periods and the bird species studied by each monitored area of Portugal and Spain. There is a striking difference between Portugal and Spain regarding the studies performed on the biomonitoring of metals using raptors. To our knowledge, to date only six of these studies have been performed in Portugal. Although these studies have enclosed several areas of the country, there is still a lack of information, especially regarding the centre and the southern coast of the country. In Spain, despite several studies being carried out, there are still many areas (mainly in the North and West) that have not been monitored.

Amongst the most sampled bird species, the Common buzzard stands out as having been monitored over practically the entire Iberian Peninsula, while the Eagle owl and the Black kite were mostly sampled in Murcia, south-eastern Spain and in Doñana National Park, south-western Spain, respectively. Concerning the analysed metals, unlike Hg that was mostly analysed in Portugal and south-west Spain, $\mathrm{Pb}$ was monitored over a larger number of geographic areas.

The monitored area is often closely related to the purpose of each study and the location of specific sources of metals, such as environmental disasters, industry, agriculture, hunting activities or urbanization. For example, in the south-west of Spain, some studies were carried out after an environmental disaster (Aznalcóllar toxic spill) in order to evaluate its effects on bird populations (Benito et al. 1999; Baos et al. 2006a, 2006b). The selection of the area to monitor is also related with the distribution of the species intended to be used as monitors and its consequent conservation status. For example, research with threatened species like the Spanish imperial eagle has been made in central Spain and Doñana National Park, south-western Spain. Before the 
226 reintroduction project of the Bearded vulture in the Southern Iberian Mountains (LIFE04

227 NAT/ES/000056), the Iberian population was only distributed in the Pyrenees, and thus

228 research studies on this species were limited to this geographical area (Hernández and

229 Margalida 2009).

230 Furthermore, the geographic location of the research groups also influences the 231 monitored areas. The research groups who have taken on the monitoring of raptors as a 232 major branch of their research are located in Spain, namely in Doñana (south-west), 233 Madrid (central), Barcelona (north-east) and Murcia (south-east). For this reason, central, 234 north-eastern and southern Spain are the areas in which a greatest number of studies have 235 been performed. The research groups in central and south-western Spain have focused to 236 a high degree on two species with an unfavourable conservation status (Black kite and 237 Spanish Imperial eagle) and the studies carried out in the south-east and north-east Spain 238 have covered a greater variety of species with a more favourable conservation status. In 239 Portugal, because there are not any research groups primarily directed towards 240 monitoring environmental contaminants with raptors, only a few isolated studies have 241 been performed.

242 The earliest monitoring studies started in 1980s in central and south-west Spain, 243 mainly focused on the Spanish Imperial eagle species (Hernández et al. 1986, 1988a; 244 González and Hiraldo 1988). It was during the period between 1997 and 2005 that the 245 majority of investigations were performed and therefore a greater number of species and 246 areas were evaluated. In recent years there has been a decrease in investigations directed 247 to the biomonitoring of toxic metals with raptors in Spain, which perhaps is strongly 248 related with a reduction in funding for research and development by the Spanish 249 government in 2011 (Margalida 2012). In Portugal such studies have been scarce. The 
250 first study was published in 2005 with the Bonelli's eagle (Palma et al. 2005), after which

251 only three studies were published with new results about the metal levels in raptors 252 (Lourenço et al. 2011; Carneiro et al. 2014, 2015).

253 The research carried out in both countries has been sporadic in terms of both time 254 and location, and using different type of samples and species (e.g. Hernández et al. 1986, 255 1988b; González et al. 1984; Negro et al. 1993; Mateo et al. 1999; Donázar et al. 2002; 256 Figueira et al. 2009; Hernández and Margalida 2009; Rodriguez-Ramos et al. 2011). 257 Furthermore some of the studies have focused on isolated events or potential sources, 258 such as the Aznalcóllar toxic spill, solid-waste incinerators and mining areas (Benito et 259 al. 1999; Blanco et al. 2003; Baos et al. 2006a, 2006b; Gómez-Ramírez et al. 2010). As 260 such, the available information does not allow making a temporal and spatial analysis 261 regarding metal concentrations. Nonetheless, studies in the South-east Spain (Murcia) 262 with the Common Buzzard and Eagle owl showed that $\mathrm{Pb}$ exposure has decreased in the 263 last 20 years (García-Fenández et al. 1995, 1997; Martínez-López et al. 2004; Gómez264 Ramírez et al. 2010; Espín et al. 2014b), which could be explained by the closure of 265 mines in 1991 and the ban on leaded petrol in 2001 (García-Fenández et al. 2005; Espín 266 et al. 2014b). Mateo et al. (2007) also found a decrease in the number of $\mathrm{Pb}$ shot in the 267 pellets of the Spanish Imperial Eagle from South Spain over the course of time, which 268 may be due to the ban of waterfowl hunting. However, in Portugal, a recent study with 269 the Common Buzzard showed higher blood $\mathrm{Pb}$ concentrations than those found in the 270 studies performed in South-east Spain and previously mentioned. On the other hand, 271 Common buzzards sampled in North-west Spain (Galicia) presented higher hepatic 272 concentrations of $\mathrm{As}, \mathrm{Cd}, \mathrm{Hg}$ and $\mathrm{Pb}$ than those sampled in Portugal and South-east Spain 273 (García-Fernández et al. 1995, 1997; Hermoso de Mendoza et al. 2006; Pérez-López et al. 
274 2008; Castro et al. 2011; Carneiro et al. 2014). The studies carried out in South-west of

275 Spain after the Aznalcóllar toxic spill, revealed a decreasing trend over time during the 276 period between 1999 and 2002 in the levels of $\mathrm{As}$ and $\mathrm{Pb}$ in Black kites from the affected 277 area (Benito et al. 1999; Baos et al. 2006a, 2006b). Nonetheless, Black kites sampled in 278 Madrid in 2001, presented blood $\mathrm{Pb}$ levels higher than those reported for birds sampled in 279 the area affected by the toxic spill regardless the year (Blanco et al. 2003).

\subsection{Type of samples}

The 44 biomonitoring studies with raptors carried out in Portugal and Spain have measured metals in a variety of different biological samples. In table 3 are listed the metals and metalloids measured in each raptor species from Portugal and Spain per sample type and the total number (n) of the different analysed samples for each species.

Choosing the type of samples to be used depends directly on the ultimate aim of the study and, in a great degree, on the kinetics of the metals to be analysed. Furthermore, the number of available samples is conditioned by several issues such as ethics, legal issues, census, and human and financial resources (García-Fernández et al. 2008). For example, the conservation status of a species is a conditioning factor in selecting the sample type, so samples that can be collected from live birds in a non-destructive way are preferred.

Blood has been the preferred sample in most biomonitoring studies performed in Portugal and Spain, in order to measure the concentrations of all studied elements. Blood samples provide the most direct and non-lethal assessment of dietary exposure, primarily reflecting recent exposure and to a lesser extent recently metabolized contaminants 296 (Evers et al. 2005; Shlosberg et al. 2011; Alvárez et al. 2013). Moreover, blood levels 297 strongly correlate with concentrations in other internal tissues and blood samples can be 
easily and repeatedly obtained from the same individual if required (García-Fernández et al. 1996; Burger and Gochfeld 1997; Kahle and Becker 1999; Kenow et al. 2007).

Non-invasive samples such as eggs and feathers have also been collected in some species. In the initial periods of biomonitoring with raptors in Spain, eggs were frequently collected to evaluate a variety of different metals in twelve raptor species (González et al. 1984; Hernández et al. 1986, 1988a, 1988b; González and Hiraldo 1988; Negro et al. 1993). Perhaps because eggs are not indicative of exposure in all individuals of the population, such as males and juvenile birds, and it is difficult to obtain a sufficient number of samples, they have not often been collected in more recent studies. However, they are a homogenous sample that can be directly related with reproductive effects, which is particularly important in the case of birds with an unfavourable conservation status (Hernández et al. 1988a; Negro et al. 1993; Hargreaves et al. 2010; GómezRamírez et al. 2014).

In recent years the usefulness of feathers as a biomarker of metals exposure has been investigated, and in Portugal and Spain they have been frequently used in recent studies to evaluate mainly $\mathrm{Hg}$ and $\mathrm{Pb}$ exposure (Martínez-López et al. 2004; Pain et al. 2005; Palma et al. 2005; Ortego et al. 2006; Figueira et al. 2009; Cardiel et al. 2011; Castro et al. 2011; Lourenço et al. 2011; Rodriguez-Ramos et al. 2011; Debén et al. 2012; Martínez et al. 2012; Espín et al. 2014c). The use of feathers has several advantages over other tissues for the measurement of metals contamination in birds. Feathers are easy to collect non-invasively, from both dead and living birds, or can be easily found in nests, which is particularly appropriate for rare and declining species; and since they do not require refrigeration, feathers can be easily stored for decades which makes them useful for longterm studies (Movalli 2000; Adout et al. 2007; Lodenius and Solonen 2013). Moreover, 
322 the specific incorporation of metals in feathers renders profiles inert and stable and may 323 lead to higher concentrations than in internal tissues, particularly for $\mathrm{Hg}$, so those 324 concentrations in feathers can be more easily measured (Furness et al. 1986; Dauwe et al. 325 2000; Burger et al. 2008; Burger and Gochfeld 2009). What is more, some studies 326 indicate that it is possible to correlate metal levels in feathers with concentrations in 327 blood and internal tissues (Dauwe et al. 2002; Martínez-López et al. 2004, 2005). 328 However, there are some factors that influence the deposition of metals into feathers, 329 such as variation between feathers, variation between different parts of a feather, 330 moulting patterns and changes of diet during moulting, which make the interpretation of 331 metal levels difficult (Dauwe et al. 2003; Jaspers et al. 2004; Debén et al. 2012; Martínez 332 et al. 2012). With the exception of $\mathrm{Hg}$, alongside endogenous deposition, external 333 contamination (atmospheric deposition or during preening) may have an important 334 impact on the metal concentrations found in feathers, which can also make the 335 interpretation of the results difficult (Dauwe et al. 2002, 2003; Jaspers et al. 2007; 336 Lodenius and Solonen 2013). In order to avoid the problem of external contamination, 337 Cardiel et al. 2011 recommends the analysis of metals in the feather rachis. Except the 338 barbs of new or actively growing feathers, barbs are more prone to surface contamination. 339 The authors also recommend the routine use of aluminium (Al) analysis in studies 340 regarding metal analysis in feathers, in order to improve the interpretation of those data.

341 Different non-invasive methods, such as the collection of regurgitated pellets, have 342 also been carried out and used to evaluate $\mathrm{Pb}$ exposure (Mateo et al. 1999, 2001, 2007). 343 Like blood samples, they can give information on the exposure frequency, seasonality 344 and the food items associated with metal exposure, however these methods can 
345 sometimes be difficult to accomplish in raptors from wooded or mountainous areas, 346 especially out of the breeding season (Mateo et al. 1999).

347 Despite the difficulties inherent to the collection of internal tissues, they have also 348 been collected for monitoring metal exposure and assessing their risk on bird populations 349 from Portugal and Spain. Most metals are stored in internal tissues such as the liver, 350 kidneys and bones, which have a tendency to accumulate them over time. Consequently 351 these tissues contain higher concentrations of some metals than those that are generally 352 found in the blood and other tissues of the birds (García-Fernández et al. 1996, 1997; Ek 353 et al. 2004; Naccari et al. 2009). The concentrations of metals in internal tissues represent 354 the levels of metals in the diet, which in turn reflect the degree of contamination of the 355 ecosystem (Monteiro et al. 1998; Castro et al. 2011). Collaboration with WRCs can 356 provide a sufficiently large number of such samples. However, the interpretation of 357 results requires great care, since the cause of death or illness may interfere with the 358 kinetics of certain compounds. In Spain, most studies were preferentially performed using 359 liver and bone samples followed by the kidney. The liver is the first target of most 360 elements and consequently it can be a good indicator of recent exposure (Braune and 361 Gaskin 1987; Scheuhammer 1987; Battaglia et al. 2005), for this reason it was used to 362 measure the concentrations of all studied metals in many bird species. Bone was the 363 preferred sample for evaluating $\mathrm{Pb}$ exposure because it is a long-term repository for this 364 metal, containing approximately $90 \%$ of the total body burden in mammals and birds and 365 reflecting life-time exposure (Scheuhammer 1987; García-Fernández et al. 1997; Mateo 366 et al. 2003; Gangoso et al. 2009). The kidney has been mainly analysed to measure Cd 367 concentrations, since this organ accumulates about one half of the Cd total body burden 368 and its $\mathrm{Cd}$ content is extremely stable. Therefore the kidney is considered an adequate 
369 biomarker of chronic exposure to Cd (Scheuhammer 1987; García-Fernández et al. 1996).

370 Other internal tissues, such as the brain, are not frequently used for monitoring metals

371 due to its low rate of accumulation there (García-Fernández et al. 1996, 1997).

372

373

\subsection{Analytical techniques used in the determination of metals and metalloids}

The analytical techniques commonly used for metals detection in biological samples of raptors from Portugal and Spain have been atomic spectroscopy methods such as 376 Atomic Absorption Spectrometry (AAS), the voltammetric stripping technique Anodic 377 Stripping Voltammetry (ASV), Inductively Coupled Plasma-Atomic Emission Spectrometry (ICP-AES) and Inductively Coupled Plasma-Mass Spectrometry (ICP-MS) 379 (Table 4).

380 The element(s) to be analysed, the sensitivity of the technique to the respective 381 element(s) and the associated costs were the main factors which influenced the selection 382 of the detection method. Except for Hg determination, Graphite Furnace (GF) - AAS and 383 ASV have been the most frequently performed techniques to determine most of the 384 metals, due to their relative cost and the sensitivity of the techniques. For determination 385 of $\mathrm{Hg}$, Cold Vapour (CV) - AAS method has always been the preferred technique, while 386 the most recent investigations used a single-purpose atomic absorption spectrometer 387 (direct $\mathrm{Hg}$ analyser) by applying additional steps in the CV-AAS procedure. ICP-MS is 388 also very sensitive and it has recently been applied to various biological matrices.

389 The major drawback of AAS techniques (flame, graphite furnace, hydride generation 390 and cold vapour) is the impossibility of performing simultaneous multi-elemental analysis. The ASV technique, modified by García-Fenández et al. (1995), has shown to

392 be very useful, mainly in the measurement of blood $\mathrm{Cd}$ concentrations, as it has detection 
393 limits that were equivalent or lower than those of the ICP-MS (García-Fernández et al. 394 1995, 1996; Espín et al. 2014a). The major drawbacks are the difficulties associated with 395 handling, storage and disposal of its $\mathrm{Hg}$ based electrodes, difficulties which make its 396 application undesirable. In fact, environmental regulations and health considerations 397 restrict its continuous application due to the high toxicity of $\mathrm{Hg}$ (Stankovic et al. 2011). 398 ICP-MS technique is a very powerful tool for the determination of metals at ultra-trace 399 levels in different matrices, allowing simultaneous multi-elemental analysis with high 400 sensitivity. ICP-MS combines the simultaneous multi-element capabilities of ICP-OES 401 techniques with exceptional detection limits, equivalent or lower than those of GF-AAS 402 (Thomas 2001; Cornelis and Nordberg 2007). However, its major drawbacks - high 403 purchase and running costs and highly skilled laboratory operator required - are the main 404 reasons for its infrequent use in biomonitoring studies with raptors in the Iberian 405 Peninsula. Although the purchase cost of an ICP-MS device is high, it has a high level of 406 productivity and becomes comparatively economical when many samples and/or 407 elements need to be determined.

408 A number of methodological issues complicate the literature concerning the levels and 409 effects of metals on organisms, populations, and ecosystems and influence our ability to 410 compare tissue levels. These mainly include changes in technology over the years, the use 411 of wet weight (w.w.) vs. dry weight (d.w.), statistical calculation (for example, use of 412 arithmetic mean and geometric mean) and the non-standardization of the quantification 413 limits calculation. Changes in technology mainly influence detection levels, which in turn 414 affects the number of samples with detectable levels. 
417 1.5. Metals and metalloids studied and concentrations obtained

418 According to the results found in the literature, in the table 5.1 and 5.2 are listed the 419 ranges of the means of the metals and metalloid concentrations found in blood and tissues 420 of the studied raptor species from Portugal and Spain.

421 Both essential and non-essential metals have been analysed, but the essential metals 422 have received the least interest. $\mathrm{Cu}$ and $\mathrm{Zn}$ were the essential metals most frequently 423 analysed; $\mathrm{Cu}$ has been analysed mainly in eggs and $\mathrm{Zn}$ in liver and also in the eggs of 424 different raptor species. Se was only evaluated in the blood of three raptors species from 425 the south-west of Spain. In general, the concentrations of $\mathrm{Zn}, \mathrm{Cu}$ and $\mathrm{Se}$ in the bird 426 species studied were within the healthy range of physiological levels in several bird 427 species, including several raptor species (Blanco et al. 2003; Baos et al. 2006a, 2006b; 428 Pérez-López et al. 2008; Alvárez et al. 2013; Espín et al. 2014a, 2014b).

429 Regarding the non-essential elements, $\mathrm{Pb}$ and $\mathrm{Cd}$ have been the most studied, while $430 \mathrm{Hg}$ and As have received the least interest.

$431 \mathrm{~Pb}$ is one of the most toxic metals and has historically been shown to affect wildlife 432 (Fisher et al. 2006; Guitart et al. 2010; Bedrosian et al. 2012). In the Iberian Peninsula, 433 contamination deriving from hunting activities has increased in relative importance in 434 recent decades and consequently it has received special concern, particularly when the 435 birds have scavenger feeding habits and an unfavourable conservation status. Numerous 436 authors have presented the $\mathrm{Pb}$ risk to raptors in Spain, including predators and scavengers 437 (Mateo et al. 2001; Donázar et al. 2002; García-Fernández et al. 2005b; Pérez-López et 438 al. 2008; Hernández and Margalida 2009). It has been a limiting factor for the 439 conservation of some endangered species, as the Pyrenean bearded vulture (Hernández 440 and Margalida 2009, Mateo et al. 2015), Egyptian vulture (Donázar et al. 2002; Gangoso 
441 et al. 2009) and Spanish imperial eagle (Pain et al. 2005; Rodriguez-Ramos et al. 2011).

$442 \mathrm{~Pb}$ shot in regurgitated pellets of raptors has been documented in the Red kite (Mateo et 443 al. 2001, 2007), Marsh harrier (Mateo et al. 1999, 2007), Spanish imperial eagle (Mateo 444 et al. 2001, 2007) and Peregrine falcon (Mateo et al. 2007). Pb poisoning has been 445 described in the Golden eagle (Cerradelo et al. 1992), Spanish Imperial eagle (Hernández 446 1995), Eagle owl, Red kite (Mateo et al. 2003) and in four species of vultures: Griffon 447 vulture (Mateo et al. 1997a), Cinereous vulture (Hernández and Margalida 2008), 448 Bearded vulture (Hernández and Margalida 2009) and Egyptian vulture (Rodriguez449 Ramos et al. 2009). Elevated concentrations of Pb have been detected in blood of Griffon 450 vultures both in Portugal and Spain (García-Fernández et al. 2005b; Espín et al. 2014a; 451 Carneiro et al. 2015). Besides acute toxicity, it has also been observed subtle detrimental 452 effects of $\mathrm{Pb}$ in some species, namely reduction on bone mineralization in Egyptian 453 vulture (Gangoso et al. 2009); biochemical changes such as decreased on $\delta$ 454 aminolevulinic acid dehydratase ( $\delta$-ALAD) activity, an enzyme participating in the 455 synthesis of haeme group in the erythrocyte, in Booted eagle (Hieraaetus pennatus), 456 Common buzzard, Northern goshawk and Eagle owl (Martínez-López et al. 2004; 457 Gómez-Ramírez et al. 2010); and oxidative damage in Griffon vultures (Espín et al. 458 2014).

$459 \mathrm{Cd}$, as well as $\mathrm{Pb}$, is a persistent and ubiquitous metal that can cause several 460 deleterious effects in living beings (Burger 2008). In general, in the studies carried out in 461 Portugal and Spain, it has been the element with the lowest concentrations in all types of 462 analysed samples (Table 5.1, 5.2) and the blood $\mathrm{Cd}$ concentrations are often below the 463 detection limits of commonly used techniques (García-Fernández et al. 1995; Carneiro et 464 al. 2014, 2015, Ortiz-Santaliestra et al. 2015). The highest blood Cd concentrations were 
465 obtained for the Black kite feeding in the area affected by a toxic spill (Doñana National 466 Park, south-west Spain) (Benito et al. 1999) and for the Northern goshawk from a non467 polluted Mediterranean forest (Murcia, south-eastern Spain) (Martinez-López et al. 468 2005), but the researchers considered that concentrations were generally low. Regarding 469 the concentrations in internal tissues, the highest concentrations were observed in the 470 liver of the Tawny owl and Long-eared owl from Galicia (north-west Spain) (Pérez471 López et al. 2008). Scheuhammer (1987) suggested that Cd levels above $3 \mu \mathrm{g} / \mathrm{g}$ d.w. in 472 liver and above $8 \mu \mathrm{g} / \mathrm{g} \mathrm{d.w}$. in kidney might indicate increased environmental exposure. 473 According to these thresholds, it is possible that there is an increased environmental 474 exposure to $\mathrm{Cd}$ mainly in north-west Spain. Renal and hepatic $\mathrm{Cd}$ concentrations 475 described in raptors from Portugal and Spain are lower than the suggested threshold 476 tissue concentrations, above which $\mathrm{Cd}$ acute intoxication might be expected $(40 \mu \mathrm{g} / \mathrm{g}$ 477 w.w. in liver and $100 \mu \mathrm{g} / \mathrm{g}$ w.w. in kidney) (Furness 1996) (Table 5.1). The Cd 478 concentrations in eggs are not believed to have caused adverse effects on reproductive 479 success or shell thickness (González et al. 1984; Hernández et al. 1986, 1988a, 1988b; 480 González and Hiraldo 1988). However, Cd exposure, even at low levels, seems to be 481 associated with genotoxic effects and immunological stress in Black kites (Blanco et al. 482 2004; Baos et al. 2006b).

483 Comparatively with $\mathrm{Pb}$ and $\mathrm{Cd}$, few studies have evaluated the exposure to $\mathrm{Hg}$ in 484 raptors from Portugal and Spain. However, $\mathrm{Hg}$ has been a contaminant of concern 485 because it accumulates in the tissues of wildlife species and can adversely affect their 486 reproduction, especially in higher trophic level species (Wolfe et al. 1998; Scheuhammer 487 et al. 2007; Tartu et al. 2013). Although Hg biomagnification in predatory birds is 488 generally greater in aquatic than in terrestrial food webs, some studies have found large 
489 accumulations of $\mathrm{Hg}$ in birds at the top of terrestrial trophic chains (Palma et al. 2005; 490 Figueira et al. 2009; Lourenço et al. 2011). Furthermore, the relatively high blood Hg 491 concentrations observed in the Peregrine falcon (south-west of Spain) and in the 492 Common buzzard (Portugal) (Alvárez et al. 2013; Carneiro et al. 2014) support the 493 hypothesis of the transport of aquatic $\mathrm{Hg}$ into the adjacent terrestrial food web, proposed 494 by Cristol et al. (2008). Although all mean blood-Hg levels detected in the studies 495 performed in Portugal and Spain were lower than the threshold that is reported as high 496 risk for avian piscivores (i.e. Common loon, Gavia immer) of $300 \mu \mathrm{g} / \mathrm{dl}$ (Evers et al. 497 2008), the sensitivity of the species to toxic elements varies considerably and toxicity 498 threshold have not yet been established for raptors. According to the Hg threshold level 499 of $3 \mu \mathrm{g} / \mathrm{dl}$ associated with alterations in antioxidant enzymes' activity (Espín et al. 2014a, 500 2014b), many birds could end up being susceptible to suffering sub-lethal effects related 501 with oxidative stress. Regarding Hg levels in feathers and eggs, Palma et al. (2005) found 502 a strong relationship between them, with feather levels of $4.1 \mu \mathrm{g} / \mathrm{g} \mathrm{w}$.w. corresponding to 503 eggs containing the benchmark of $1.0 \mu \mathrm{g} / \mathrm{g} \mathrm{w} . \mathrm{w}$, which is the lowest concentration 504 associated with deformities of particularly sensitive embryos, though it is unlikely to 505 affect more than a small percentage of eggs (Heinz and Hoffman 2003). Therefore, it is 506 unlikely that $\mathrm{Hg}$ contamination can negatively affect the reproduction of the studied bird 507 populations. The initial research studies (1980s) carried out with eggs in the south-west 508 and central Spain, reached this same conclusion (González et al. 1984; Hernández et al. 509 1986, 1988a; González and Hiraldo 1988). However, sub-lethal effects are likely to occur 510 at concentrations far lower than those required to produce more pronounced pathological 511 effects (Scheuhammer 1987; Thompson 1996). 
512 As was the least studied toxic element in raptors from Portugal and Spain perhaps 513 because, despite being a toxic metalloid, it has a low rate of bioaccumulation and it is not 514 biomagnified in the food chain (Eisler 1998; Hughes 2006). The As concentrations 515 obtained in the studied species could be considered as indicative of low and background 516 amounts, of no ecotoxicological concern (Blanco et al. 2003; Baos et al. 2006a, 2006b; 517 Pérez-López et al. 2008; Carneiro et al. 2014).

\section{2. Conclusion}

520 In conclusion, the analysis of toxic metals in different tissues of raptors has been an 521 important tool for assessing environmental contamination by these elements in Portugal 522 and Spain. Several studies using a range of sentinel raptor species have been carried out 523 since the 1980s. However, there is a striking difference between the number of studies 524 performed in Portugal and Spain, having been scarce in Portugal.

525 The Eagle owl, Black kite and Common buzzard were the species from which the 526 greatest number of individuals have been analysed. Due to conservation problems, the 527 Spanish Imperial eagle was also the subject of several biomonitoring studies. The study 528 of other raptor species that have demonstrated their usefulness in matters of conservation 529 and environmental risk assessment is recommended.

530 The studies performed have measured the metal concentrations in a variety of different 531 biological samples employing different analytical techniques. Blood was the type of 532 sample collected in the greatest number, followed by feathers, liver and bone. Feathers 533 have been frequently collected in recent studies to evaluate mainly $\mathrm{Hg}$ and $\mathrm{Pb}$ exposure.

534 Blood and liver were used to measure the concentrations of all studied metals in many 535 bird species, while bone was mainly collected to evaluate chronic $\mathrm{Pb}$ exposure. 
536 Regarding analytical techniques, AAS has been the most frequently performed technique 537 to determine most of the metals and metalloids, mainly due to its relatively low cost and 538 good sensitivity. The high cost of ICP-MS has limited its application. However this 539 technique allows simultaneous multi-elemental analysis with higher sensitivity and it has 540 a high productivity, becoming comparatively economical when many samples and/or 541 elements need to be determined.

542 In general, the concentrations of metals detected in raptor samples from Portugal and 543 Spain are generally low and of an insufficient level to produce toxic side effects. Only $\mathrm{Pb}$, 544 in certain cases, can be related to toxic side effects and it has been a limiting factor in the 545 conservation of some endangered species, such as the Pyrenean bearded vulture, Egyptian 546 vulture and Spanish imperial eagle. Although in Spain, the Griffon vulture has a positive 547 population trend, in Portugal $\mathrm{Pb}$ exposure could be a risk for the conservation of this 548 endangered species. Even though $\mathrm{Pb}$ has received the greatest level of concern among 549 researchers, more efforts are necessary to assess its risk to the conservation of other 550 endangered species and to human health. Regarding $\mathrm{Hg}$, the transport of the aquatic into 551 the adjacent terrestrial food web, the lack of information concerning its exposure in many 552 raptor species and the need to establish the toxicity threshold $\mathrm{Hg}$ for raptors, support the 553 need for further biomonitoring studies of this metal.

554 The research carried out in Portugal and Spain has been sporadic in terms of both time 555 and space. Financial support has been the main limiting factor in implementing 556 biomonitoring studies with raptors on a large spatial and temporal scale. However, given 557 the toxicity of the metals and As, it is advisable to establish at a national scale, both in 558 Portugal and Spain, biomonitoring programmes using raptors in order to conduct long559 term studies that would link the survival of birds to their contaminant burdens. A network 
560 needs to be developed between the two countries and between toxicologists, veterinarians

561 and ornithologists studying raptor populations to encompass analysis of samples collected

562 in WRCs and by ornithologists. Coordination between existing biomonitoring schemes in

563 other European countries and expansion of monitoring into other European countries is

564 also needed.

565

566 Acknowledgments: This study was supported by the Fundação para a Ciência $e$

567 Tecnologia: post-graduation grants to M. Carneiro (SFRH/BD/62115/2009) and to Ana I.

568 Faustino (SFRH/BD/102099/2014). 


\section{References}

570 Adout, A., Hawlena, D., Mamana, R., Paz-Tal, O., Karpas, Z. 2007. Determination of 571 trace elements in pigeon and raven feathers by ICPMS. Int. J. Mass Spectrom. 267(1-3): 109-116. doi:10.1016/j.ijms.2007.02.022.

573 Alleva, E., Francia, N., Pandolfi, M., De Marinis, A.M., Chiarotti, F., Santucci, D. 2006. Organochlorine and heavy-metal contaminants in wild mammals and birds of Urbino-Pesaro Province, Italy: an analytic overview for potential bioindicators. Arch. Environ. Contam. Toxicol. 51(1): 123-134. doi:10.1007/s00244-005-02181.

Alvárez, C.R., Moreno, M.J., Alonso, L.L., Gómara, B., Bernardo, F.J., MartínDoimeadios, R.C., González, M.J. 2013. Mercury, methylmercury, and selenium in blood of bird species from Doñana National Park (Southwestern Spain) after a mining accident. Environ. Sci. Pollut. Res. 20(8): 5361-5372. doi: 10.1007/s11356-013-1540-1.

Anthony, R.G, Garret, M.G., Schuler, C.A. 1993. Environmental contaminants in bald eagle in the Columbia River estuary. J. Wildl. Manage. 57(1): 10-19.

Arroyo, B.E. 1997. Diet of Montagu's Harrier Circus pygargus in central Spain: analysis of temporal and geographic variation. Ibis. 139(4): 664-672. doi: 10.1111/j.1474919X.1997.tb04689.x.

Baos, R., Jovani, R., Forero, M.G., Tella, J.L., Gómez, G., Jiménez, B., González, M.J., Hiraldo, F. 2006a. Relationships between T-cell-mediated immune response and $\mathrm{Pb}, \mathrm{Zn}, \mathrm{Cu}, \mathrm{Cd}$, and as concentrations in blood of nestling white storks (Ciconia ciconia) and black kites (Milvus migrans) from Donana (southwestern Spain) 
592

593

594

595

596

597

598

599

600

601

602

603

604

605

606

607

608

609

610

611

612

613

614

after the Aznalcollar toxic spill. Environ. Toxicol. Chem. 25(4): 1153-1159. doi: 10.1897/05-395R.1.

Baos, R., Jovani, R., Pastor, N., Tella, J.L., Jiménez, B., Gómez, G., González, M.J., Hiraldo, F. 2006b. Evaluation of genotoxic effects of heavy metals and arsenic in wild nestling white storks (Ciconia ciconia) and black kites (Milvus migrans) from southwestern Spain after a mining accident. Environ. Toxicol. Chem. 25(10): 2794-2803. doi: 10.1897/05-570R.1.

Barbosa, F. Jr., Farina, M., Viegas, S., Kempinas, W.D., G. 2014. Toxicology of metals and metalloids. Biomed. Res. Int. 2014: 253738. doi: 10.1155/2014/253738.

Battaglia, A., Ghidini, S., Campanini, G., Spaggiari, R. 2005 Heavy metal contamination in little owl (Athene noctua) and common buzzard (Buteo buteo) from northern Italy. Ecotoxicol. Environ. Saf. 60(1): 61-66. doi: 10.1016/j.ecoenv.2003.12.019

Becker, P.H. 2003. Biomonitoring with birds. In Trace Metals and other Contaminants in the Environment Bioindicators and Biomonitors: Principles, Concepts and Applications. Edited by B.A. Markert, A.M. Breure, H.G. Zechmeister. Elsevier, Oxford. pp. 677-736.

Bedrosian, B., Craighead, D., Crandall, R. 2012. Lead exposure in bald eagles from big game hunting, the continental implications and successful mitigation efforts. PLoS One 7(12): e51978. doi. 10.1371/journal.pone.0051978.

Beeby, A. 2001. What do sentinels stand for? Environ. Pollut. 112(2): 285-298. doi:10.1016/S0269-7491(00)00038-5.

Benito, V., Devesa, V., Muñoz, O., Suñer, M.A., Montoro, R., Baos, R., Hiraldo, F., Ferrer, M., Fernández, M., González, M.J. 1999. Trace elements in blood 
collected from birds feeding in the area around Doñana National Park affected by the toxic spill from the Aznacóllar mine. Sci. Total. Environ. 242 (1-3): 309-323.

Berglund, A.M., Sturve, J., Forlin, L., Nyholm, N.E. 2007. Oxidative stress in pied flycatcher (Ficedula hypoleuca) nestlings from metal contaminated environments in northern Sweden. Environ. Res. 105(3): 330-339. doi: 10.1016/j.envres.2007.06.002.

BirdLife International. 2004. Birds in Europe: Population Estimates, Trends and Conservation Status. BirdLife International. Cambridge.

Blanco, G., Frias, O., Jimenez, B., Gomez, G. 2003. Factors influencing variability and potential uptake routes of heavy metals in black kites exposed to emissions from a solid-waste incinerator. Environ. Toxicol. Chem. 22(11): 2711-2718. doi: 10.1897/02-519.

Blanco, G., Jiménez, B., Frías, O., Millan, J., Dávila, J.A. 2004. Contamination with nonessential metals from a solid-waste incinerator correlates with nutritional and immunological stress in prefledgling black kites (Milvus migrans). Environ. Res. 94(1): 94-101. doi: 10.1016/S0013-9351(03)00120-8.

Braune, B.M., Gaskin, D.E. 1987. Mercury levels in Bonaparte's gulls (Larus philadelphia) during autumn molt in the Quoddy Region, New Brunswick, Canada. Arch. Environ. Contam. Toxicol. 16(5): 539-549. doi: 10.1007/BF01055810.

Burfield, I.J. 2008. The Conservation Status and Trends of Raptors and Owls in Europe. Ambio. 37(6):401-407. doi:10.1579/0044-7447(2008)37[401:TCSATO]2.0.CO;2.

Burger, J. 1995. A risk assessment for lead in birds. J. Toxicol. Environ. Health. 45(4): 369-396. doi: 10.1080/15287399509532003. 
639 Burger, J. 2008. Assessment and management of risk to wildlife from cadmium. Sci. 640 Total. Environ. 389(1): 37-45. doi: 10.1016/j.scitotenv.2007.08.037.

641 Burger, J., Gochfeld, M. 1997. Age differences in metals in the blood of herring (Larus 642 argentatus) and Franklin's (Larus pipixcan) gulls. Arch. Environ. Contam. 643 Toxicol. 33(4): 436-440. doi: 10.1007/s002449900274.

644 Burger, J., Gochfeld, M., Jeitner, C., Snigaroff, D., Snigaroff, R., Stamm, T., Volz, C. 645 2008. Assessment of metals in down feathers of female common eiders and their 646 eggs from the Aleutians: arsenic, cadmium, chromium, lead, manganese, mercury, 647 and selenium. Environ. Monit. Assess. 143(1-3): 247-256. doi: 10.1007/s10661007-9973-y.

Burger, J., Gochfeld, M. 2009. Mercury and other metals in feathers of common eider (Somateria mollissima) and tufted puffin (Fratercula cirrhata) from the Aleutian chain of Alaska. Arch. Environ. Contam. Toxicol. 56(3): 596-606. doi: 10.1007/s00244-008-9207-5.

Cabral, M.J., Almeida, J., Almeida, P.R., Dellinger, T., Ferrand de Almeida, N., Oliveira, M.E., Palmeirim, J.M., Queiroz, A.J., Rogado, L., Santos-Reis, M. 2005. Livro Vermelho dos Vertebrados de Portugal. Instituto da Conservação da Natureza, Lisboa, Portugal.

Cardador, L., Planas, E., Varea, A., Mañosa, S. 2012. Feeding behaviour and diet composition of Marsh Harriers Circus aeruginosus in agricultural landscapes. Bird Study. 59: 228-235. doi: 10.1080/00063657.2011.648165.

Cardiel, I.E., Taggart, M.A., Mateo, R. 2011. Using Pb-Al ratios to discriminate between internal and external deposition of $\mathrm{Pb}$ in feathers. Ecotoxicol. Environ. Saf. 74(4):

662 911-917. doi: 10.1016/j.ecoenv.2010.12.015. 
663 Carneiro, M., Colaço, B., Brandão, R., Ferreira, C., Santos, N., Soeiro, V., Colaço, A., 664 Pires, M.J., Oliveira, P.A., Lavin, S. 2014. Biomonitoring of heavy metals (Cd, $665 \mathrm{Hg}$, and $\mathrm{Pb}$ ) and metalloid (As) with the Portuguese Common buzzard (Buteo 666 buteo). Environ. Monit. Assess. 186(11): 7011-7021. doi: 10.1007/s10661-014$667 \quad 3906-3$.

668 Carneiro, M., Colaço, B., Brandão, R., Azorín, B., Nicolas, O., Colaço, J., Pires, M.J., 669 Agustí, S., Casas-Díaz, E., Lavin, S., Oliveira, P.A. 2015. Assessment of the 670 exposure to heavy metals in Griffon vultures (Gyps fulvus) from the Iberian 671 Peninsula. Ecotoxicol. Environ. Saf. 113: 295-301. doi: 672 10.1016/j.ecoenv.2014.12.016.

673 Castro, I., Aboal, J.R., Fernández, J.A., Carballeira, A. 2011. Use of raptors for 674 biomonitoring of heavy metals: gender, age and tissue selection. Bull. Environ. 675 Contam. Toxicol. 86(3): 347-351. doi: 10.1007/s00128-011-0220-4.

676 Catry, P., Costa, H., Elias, G., Matias, R. 2010. Aves de Portugal. Ornitologia do 677 território continental. Assírio \& Alvim, Lisboa.

678 Cerradelo, S., Muñoz, E., To-Figueras, J., Mateo, R., Guitart, R. 1992. Intoxicación por 679 ingestion de perdigones de plomo en dos aguilas reales. Doñana, Acta Vertebrata 680 19: (1-2): 122-127.

681 Cornelis, R., Nordberg, M. 2007. General Chemistry, Sampling, Analytical Methods, and 682 Speciation. In Handbook on the toxicology of metals. Edited by G.F. Nordberg, 683 F.A. Fowler, M. Nordberg, L.T. Fridberg. Elsevier, Amsterdam, pp 11-38.

684 Cristol, D.A., Brasso, R.L., Condon, A.M., Fovargue, R.E., Friedman, S.L., Hallinger, 685 K.K., Monroe, A.P., White, A.E. 2008. The movement of aquatic mercury 
686

687

688

689

690

691

692

693

694

695

696

697

698

699

700

701

702

703

704

705

706

707

708

through terrestrial food webs. Science. 320(5874): 335. doi: $10.1126 /$ science. 1154082 .

Dauwe, T., Bervoets, L., Blust, R., Pinxten, R., Eens, M. 2000. Can excrement and feathers of nestling songbirds be used as biomonitors for heavy metal pollution? Arch. Environ. Contam. Toxicol. 39(4): 541-546. doi: 10.1007/s002440010138.

Dauwe, T., Bervoets, L., Blust, R., Eens, M. 2002. Tissue levels of lead in experimentally exposed zebra finches (Taeniopygia guttata) with particular attention on the use of feathers as biomonitors. Arch. Environ. Contam. Toxicol. 42(1): 88-92. doi: $10.1007 / \mathrm{s} 002440010295$.

Dauwe, T., Bervoets, L., Pinxten, R., Blust, R., Eens, M. 2003. Variation of heavy metals within and among feathers of birds of prey: effects of molt and external contamination. Environ. Pollut. 124(3): 429-436. doi: 10.1016/S02697491(03)00044-7.

Debén, S., Ángel Fernández, J., Aboal, J.R., Carballeira, A. 2012. Evaluation of different contour feather types for biomonitoring lead exposure in Northern goshawk (Accipiter gentilis) and Tawny owl (Strix aluco). Ecotoxicol. Environ. Saf. 85: 115-119. doi: 10.1016/j.ecoenv.2012.08.005.

Delibes, M., Brunet-Lecomte, P., Máñez, M. 1984. Datos sobre la alimentación de la Lechuza comun (Tyto alba), el Buho chico (Asio otus) y el Mochuelo (Athene noctua) en una misma localidad de Castilla la Vieja. Ardeola. 30: 54-67.

Donázar, J.A. 1993. Los buitres ibéricos. J.M. Reyero, Madrid.

Donázar, J.A., Cortés-Avizanda, A., Carrete, M., 2010. Dietary shifts in two vultures after the demise of supplementary feeding stations: consequences of the EU 
sanitary legislation. Eur. J. Wildl. Res. 56, 613-621. doi: 10.1007/s10344-0090358-0.

Donázar, J.A., Palacios, C.J., Gangoso, L., Ceballos, O., González, M.J., Hiraldo, F. 2002. Conservation status and limiting factors in the endangered population of Egyptian vulture (Neophron percnopterus) in the Canary Islands. Biol. Cons. 107(1): 89-97. doi: 10.1016/S0006-3207(02)00049-6.

Eisler, R. 1998. Arsenic hazards to fish, wildlife, and invertebrates: a synoptic review. U.S. Fish and Wildlife Service Biological Report 85 (1.12).

Ek, K.H., Morrison, G.M., Lindberg, P., Rauch, S. 2004. Comparative tissue distribution of metals in birds in Sweden using ICP-MS and laser ablation ICP-MS. Arch. Environ. Contam. Toxicol. 47(2): 259-269. doi: 10.1007/s00244-004-3138-6.

Ernst, W.H., Verkleij, J.A., Vooijs, R. 1983. Bioindication of a surplus of heavy metals in terrestrial ecosystems. Environ. Monit. Assess. 3(3-4): 297-305. doi: 10.1007/BF00396224.

Espín, S., Martínez-López, E., León-Ortega, M., Calvo, J.F., García-Fernández, A.J. 2014a. Factors that influence mercury concentrations in nestling Eagle Owls (Bubo bubo). Sci. Total Environ. 470-471: 1132-1139. doi: 10.1016/j.scitotenv.2013.10.063.

Espín, S., Martínez-López, E., León-Ortega, M., Martínez, J.E., García-Fernández, A.J. 2014b. Oxidative stress biomarkers in Eurasian eagle owls (Bubo bubo) in three different scenarios of heavy metal exposure. Environ. Res. 131: 134-144. doi: 10.1016/j.envres.2014.03.015.

Espín, S., Martínez-López, E., Jiménez, P., María-Mojica, P., García-Fernández, A.J. 2014c. Effects of heavy metals on biomarkers for oxidative stress in Griffon 
733

734

735

736

737

738

739

740

741

742

743

744

745

746

747

748

749

750

751

752

753

754

755

vulture (Gyps fulvus). Environ. Res. 129: 59-68. doi: 10.1016/j.envres.2013.11.008.

Evers, D.C., Burgess, N.M., Champoux, L., Hoskins, B., Major, A., Goodale, W.M., Taylor, R.J., Poppenga, R., Daigle, T. 2005. Patterns and interpretation of mercury exposure in freshwater avian communities in northeastern North America. Ecotoxicology. 14: 193-221.

Evers, D.C., Savoy, L.J., DeSorbo, C.R., Yates, D.E., Hanson, W., Taylor, K.M., Siegel, L.S., Cooley, J.H., Jr., Bank, M.S., Major, A., Munney, K., Mower, B.F., Vogel, H.S., Schoch, N., Pokras, M., Goodale, M.W., Fair, J. 2008. Adverse effects from environmental mercury loads on breeding common loons. Ecotoxicology. 17(2): 69-81.

Figueira, R., Tavares, P.C., Palma, L., Beja, P., Sérgio, C. 2009. Application of indicator kriging to the complementary use of bioindicators at three trophic levels. Environ Pollut. 157(10): 2689-2696. doi: 10.1016/j.envpol.2009.05.001.

Fisher, I.J., Pain, D.J., Thomas, V.G. 2006. A review of lead poisoning from ammunition sources in terrestrial birds. Biol. Cons. 131: 421-432. doi: 10.1016/j.biocon.2006.02.018.

Florea, A.M., Busselberg, D. 2006. Occurrence, use and potential toxic effects of metals and metal compounds. Biometals. 19(4): 419-427. doi: 10.1007/s10534-005-4451$\mathrm{x}$.

Furness, R.W. 1993. Birds as monitors of pollutants. In Birds as monitors of environmental change. Edited by R.W. Furness and J.J.D. Greenwood. Chapman and Hall, London. pp. 86-143. 
756 Furness, R.W. 1996. Cadmium in birds. In Environmental contaminants in wildlife: 757 interpreting tissue concentrations, $1^{\text {st }}$ ed. Edited by W.N. Beyer, G.H. Heinz, A.W. 758 Redmon-Norwood. Lewis, Boca Raton. pp. 389-404.

759 Furness, R.W., Muirhead, S.J., Woodburn, M. 1986. Using bird feathers to measure 760 mercury in the environment: Relationships between mercury content and moult.

Garcia, J.T., Arroyo, B.E. 2005. Food-niche differentiation in sympatric Hen Circus cyaneus and Montagu's Harriers Circus pygargus. Ibis. 147(1): 144-154. doi: 10.1111/j.1474-919x.2004.00377.x.

García-Fernández, A.J., Sanchez-Garcia, J.A, Jimenez-Montalban, P., Luna, A. 1995. Lead and cadmium in wild birds in Southeastern Spain. Environ. Toxicol. Chem. 14(12): 2049-2058. doi: 10.1002/etc.5620141207.

García-Fernández, A.J., Sanchez-Garcia, J.A., Gomez-Zapata, M., Luna, A. 1996. Distribution of cadmium in blood and tissues of wild birds. Arch. Environ. Contam. Toxicol. 30(2): 252-258. doi: 10.1007/BF00215805.

García-Fernández, A.J., Motas-Guzmán, M., Navas, I., María-Mojica, P., Luna, A., Sánchez-Garcia, J.A. 1997. Environmental exposure and distribution of lead in four species of raptors in Southeastern Spain. Arch. Environ. Contam. Toxicol. 33(1): 76-82. doi: 10.1007/s002449900226. 
779 García-Fernández, A.J., Romero, D., Martínez-López, E., Navas, I., Pulido, M., María780 Mojica, P. 2005a. Environmental lead exposure in the European kestrel (Falco

781

782

783

784 tinnunculus) from southeastern Spain: the influence of leaded gasoline regulations. Bull. Environ. Contam. Toxicol. 74(2): 314-319. doi: 10.1007/s00128-004-0586-7.

García-Fernández, A.J., Martínez-Lopez, E., Romero, D., María-Mojica, P., Godino, A., Jiménez, P. 2005b. High levels of blood lead in griffon vultures (Gyps fulvus) from Cazorla Natural Park (Southern Spain). Environ. Toxicol. 20(4): 459-463. doi: 10.1002/tox.20132.

García-Fernández, A.J., Calvo, J.F., Martínez-López, E., María-Mojica, P., Martínez, J.E. 2008. Raptor ecotoxicology in Spain: a review on persistent environmental contaminants. Ambio. 37(6): 432-439. doi: 10.1579/00447447(2008)37[432:REISAR]2.0.CO;2.

García Dios, I.S. 2006. Dieta del Aguililla calzada en el Sur de Ávila: importancia de los passeriformes. Ardeola. 53(1): 39-54.

García, J.T., Viñuela, J., Sunyer, C. 1998. Geographic variation of the winter diet of the Red Kite Milvus milvus in the Iberian Peninsula. Ibis. 140(2): 302-309. doi: 10.1111/j.1474-919X.1998.tb04393.x.

Gigirey, A., Fernández, M., García, J.L. 2004. Datos sobre la alimentación de la Lechuza común (Tyto alba) en Santiago de Compostela (A Coruña). Chioglossa. 2: 27-31.

Gil, J.M., Pleguezuelos, J.M. 2001. Prey and prey-size selection by the short-toed eagle (Circaetus gallicus) during the breeding season in Granada (south-eastern Spain). J. Zool. 255(1): 131-137. doi: 10.1017/S0952836901001182. 
802 Gil-Delgado, J.A., Verdejo, J., Barba, E. 1995. Nestling diet and fledgling production of 803 Eurasian kestrels (Falco tinnunculus) in Eastern Spain. J. Raptor Res. 29(4): 240804244.

805 Golden, N.H., Rattner, B.A. 2003. Ranking terrestrial vertebrate species for utility in 806 biomonitoring and vulnerability to environmental contaminants. Rev. Environ. Contam. Toxicol. 176: 67-136.

Gómez-Ramírez, P., Martínez-López, E., María-Mojica, P., León-Ortega, M., GarcíaFernández, A.J. 2010. Blood lead levels and delta-ALAD inhibition in nestlings of Eurasian Eagle Owl (Bubo bubo) to assess lead exposure associated to an abandoned mining area. Ecotoxicology. 20(1): 131-138. doi: 10.1007/s10646010-0563-3.

Gómez-Ramírez, P., Shore, R.F., van den Brink, N.W., van Hattum, B., Bustnes, J.O., Duke, G., Fritsch, C., García-Fernández, A.J., Helander, B.O., Jaspers, V., Krone, O., Martínez-López, E., Mateo, R., Movalli, P., Sonne, C. 2014. An overview of existing raptor contaminant monitoring activities in Europe. Environ. Int. 67: 1221. doi: 10.1016/j.envint.2014.02.004.

González, L.M., Hiraldo, F. 1988. Organochlorine and heavy metal contamination in the eggs of the Spanish Imperial Eagle (Aquila (heliaca) adalberti) and accompanying changes in eggshell morphology and chemistry. Environ. Pollut. 51(4): 241-258. doi: 10.1016/0269-7491(88)90165-0.

González, L.M., Oria, J., Sánchez, R., Margalida, A., Aranda, A., Prada, L., Caldera, J., Molina, J.I. 2008. Status and habitat changes in the endangered Spanish Imperial Eagle Aquila adalberti population during 1974-2004: implications for its recovery. Bird Conserv. Int. 18: 242-259. doi: 10.1017/S0959270908000245. 
826 González, M.J., Hernández, L.M., Rico, M.C., Baleja, G. 1984. Residues of

827

828

829

830

831

832

833

834

835

836

837

838

839

840

841

842

843

844

845

846

847

848 organochlorine pesticides, polychlorinated biphenyls and heavy metals in the eggs of predatory birds from Doñana National Park (Spain), 1980-1983. J. Environ. Sci. Health, Part B. 19(8-9): 759-772. doi: 10.1080/03601238409372462.

Guitart, R., Torra, M., Cerradelo, S., Puig-Casado, P., Mateo, R., To-Figueras, J. 1994. $\mathrm{Pb}, \mathrm{Cd}, \mathrm{As}$, and Se concentrations in livers of dead wild birds from the Ebro Delta, Spain. Bull. Environ. Contam. Toxicol. 52(4): 523-529. doi: 10.1007/BF00194139.

Guitart, R., Sachana, M., Caloni, F., Croubels, S., Vandenbroucke, V., Berny, P. 2010. Animal poisoning in Europe. Part 3: Wildlife. Vet. J. 183(3): 260-265. doi: 10.1016/j.tvj1.2009.03.033.

Hargreaves, A.L., Whiteside, D.P., Gilchrist, G. 2010. Concentrations of 17 elements, including mercury, and their relationship to fitness measures in arctic shorebirds and their eggs. Sci. Total. Environ. 408(16): 3153-3161. doi: 10.1016/j.scitotenv.2010.03.027.

He, Z.L., Yang, X.E., Stoffella, P.J. 2005. Trace elements in agroecosystems and impacts on the environment. J. Trace Elem. Med. Biol. 19(2-3): 125-140. doi: 10.1016/j.jtemb.2005.02.010.

Heinz, G.H., Hoffman, D.J. 2003. Embryotoxic thresholds of mercury: estimates from individual mallard eggs. Arch. Environ. Contam. Toxicol. 44(2): 257-264. doi: $10.1007 / \mathrm{s} 00244-002-2021-6$.

Hermoso de Mendoza, M., Soler Rodríguez, F., Hernández Moreno, D., Gallego Rodríguez, M.E., López Beceiro, A., Pérez-López, M. 2006. Estudio comparativo 
849

850

851

852

853

854

855

856

857

858

859

860

861

862

863

864

865

866

867

868

869

870

871

del nivel hepático de metales pesados y metaloides en aves rapaces diurnas de Galicia y Extremadura. Rev. Toxicol. 23, 138-145.

Hernández, L.M., Rico, M.C., González, M.J., Hernan, M.A., Fernández, M.A. 1986. Presence and time trends of organochlorine pollutants and heavy metals in eggs of predatory birds of Spain. J. Field Ornithol. 57(4): 270-282.

Hernández, L.M., González, M.J., Fernandez, M.A. 1988a. Organochlorines and Metals in Spanish Imperial Eagle Eggs, 1986-87. Environ. Conserv. 15(4): 363-364. doi: $10.1017 / \mathrm{S} 0376892900029891$.

Hernández, L.M., González, M.J., Rico, M.C., Fernández, M.A., Aranda, A. 1988b. Organochlorine and heavy metal residues in falconiforme and ciconiforme eggs (Spain). Bull. Environ. Contam. Toxicol. 40(1), 86-93. doi: 10.1007/BF01689392.

Hernández, M. 1995. Lead poisoning in a free-ranging Imperial eagle. Supplement. J. Wildl. Dis. 31 (newsletter).

Hernández, M., Margalida, A. 2008. Pesticide abuse in Europe: effects on the Cinereous vulture (Aegypius monachus) population in Spain. Ecotoxicology 17(4): 264-272. doi: 10.1007/s10646-008-0193-1.

Hernández, M., Margalida, A. 2009. Assessing the risk of lead exposure for the conservation of the endangered Pyrenean bearded vulture (Gypaetus barbatus) population. Environ. Res. 109(7): 837-842. doi: 10.1016/j.envres.2009.05.001.

Hidalgo, S., Zabala, J., Zuberogoitia, I., Azkona, A., Castillo, I. 2005. Food of the Egyptian vulture (Neophron percnopterus) in Biscay. Buteo 14: 23-29.

Hollamby, S., Afema-Azikuru, J., Waigo, S., Cameron, K., Gandolf, A.R., Norris, A., Sikarskie, J.G. 2006. Suggested guidelines for use of avian species as 
biomonitors. Environ. Monit. Assess. 118(1-3): 13-20. doi: 10.1007/s10661-0060770-9.

874 Hughes, M.F. 2006. Biomarkers of exposure: a case study with inorganic arsenic. Environ. Health Perspect. 114(11): 1790-1796. doi: 10.1289/ehp.9058.

876

877

878

879

880

881

882
Jaspers, V., Dauwe, T., Pinxten, R., Bervoets, L., Blust, R., Eens, M. 2004. The importance of exogenous contamination on heavy metal levels in bird feathers. A field experiment with free-living great tits, Parus major. J. Environ. Monit. 6(4): 356-360. doi: 10.1039/B314919F.

Jaspers, V.L., Covaci, A., Van den Steen, E., Eens, M. 2007. Is external contamination with organic pollutants important for concentrations measured in bird feathers? Environ. Int. 33(6): 766-772. doi: 10.1016/j.envint.2007.02.013.

Kahle, S., Becker, P.H. 1999. Bird blood as bioindicator for mercury in the environment. Chemosphere. 39(14): 2451-2457. doi: 10.1016/S0045-6535(99)00154-X.

Kenow, K.P., Meyer, M.W., Hines, R.K., Karasov, W.H. 2007. Distribution and accumulation of mercury in tissues of captive-reared common loon (Gavia immer) chicks. Environ. Toxicol. Chem. 26(5): 1047-1055. doi: 10.1897/06-193R.1.

Korpimaki, E. 1988. Diet of breeding Tengmalm's owls Aegolius funereus: long term changes and year-to-year variation under cyclic food conditions. Ornis Fernnica. 65: $21-30$.

Lee, D.P., Lee, K.G., Nam, D.H. 2012. Population declines and heavy metal exposure of Swinhoe's Storm Petrels (Oceanodroma monorhis) breeding on the southwest coast of Korea. Mar. Pollut. Bull. 64(12): 2645-2649. doi: 10.1016/j.marpolbul.2012.10.018. 
895 Lodenius, M., Solonen, T. 2013. The use of feathers of birds of prey as indicators of 896 metal pollution. Ecotoxicology. 22(9): 1319-1334. doi: 10.1007/s10646-013897 1128-z.

898

899

900

901

902

903

904

905

906

907

908

909

910

911

912

913

914

915

916

917

López-López, P., Verdejo, J., Barba, E. 2009. The role of pigeon consumption in the population dynamics and breeding performance of a peregrine falcon (Falco peregrinus) population: conservation implications. Eur. J. Wildl. Res. 55(2): 125132. doi: 10.1007/s10344-008-0227-2.

Lourenço, R., Tavares, P.C., del Mar Delgado, M., Rabaça, J.E., Penteriani, V. 2011. Superpredation increases mercury levels in a generalist top predator, the eagle owl. Ecotoxicology. 20(4): 635-642. doi: 10.1007/s10646-011-0603-7.

Madroño, A., González, C., Atienza, J.C. 2004. Libro Rojo de las Aves de España. Dirección General para la Biodiversidad-SEO/BirdLife, Madrid.

Mañosa, S., Cordero, P.J. 1992. Seasonal and sexual variation in the diet of the Common buzzard in Northeastern Spain. J. Raptor Res. 26(4): 235-238.

Mañosa, S. 1994. Goshawk diet in a Mediterranean area of Northeastern Spain. J. Raptor Res. 28(2): 84-92.

Mañosa, S., Mateo, R., Freixa, C., Guitart, R. 2003. Persistent organochlorine contaminants in eggs of northern goshawk and Eurasian buzzard from northeastern Spain: temporal trends related to changes in the diet. Environ. Pollut. 122: 351-359. doi: 10.1016/S0269-7491(02)00334-2.

Mañosa, S., Oro, D. 1991. Contribución al conocimiento de la dieta del gavilán (Accipiter nisus) en la comarca de La Segarra (Catalunya) durante el periodo reproductor. Ardeola. 38 (2): 289-286. 
918 Margalida, A. 2012. Baits, budget cuts: a deadly mix. Science 338: 192. doi: $919 \quad 10.1126 /$ science.338.6104.192-a.

920 Margalida, A., Benítez, J.R., Sánchez-Zapata, J.A., Ávila, E., Arenas, R., Donázar, J.A. 2012. Long-term relationship between diet breadth and breeding success in a declining population of Egyptian Vultures Neophron percnopterus. 154 (1): 184188. doi: 10.1111/j.1474-919X.2011.01189.x.

Margalida, A., Bertran, J., Boudet, J. 2005. Assessing the diet of nestling Bearded Vultures: a comparison between direct observation methods. J. Field Ornithol. 76(1): 40-45. doi: http://dx.doi.org/10.1648/0273-8570-76.1.40.

Martínez-López, E., María-Mojica, P., Martínez, J.E., Calvo, J.F., Romero, D., GarcíaFernández, A.J. 2005. Cadmium in feathers of adults and blood of nestlings of three raptor species from a nonpolluted Mediterranean forest, Southeastern Spain. 
942

943

944

945

946

947

948

949

950

951

952

953

954

955

956

957

958

959

960

961

962

963

964

Bull. Environ. Contam. Toxicol. 74(3): 477-484. doi: 10.1007/s00128-005-0610-

6.

Mateo, R., Dolz, J.C., Aguilar Serrano, J.M., Belliure, J., Guitart, R. 1997a An epizootic of lead poisoning in greater flamingos (Phoenicopterus ruber roseus) in Spain. J. Wildl. Dis. 33(1): 131-134. doi: 10.7589/0090-3558-33.1.131.

Mateo, R., Molina, R., Grifols. J., Guitart, R. 1997b. Lead poisoning in a free ranging griffon vulture (Gyps fulvus). Vet. Rec. 140(2): 47-48. doi: 10.1136/vr.140.2.47.

Mateo, R., Estrada, J., Paquet, J., Riera, X., Domínguez, L., Guitart, R., Martínez-Vilalta, A. 1999. Lead shot ingestion by marsh harriers Circus aeruginosus from the Ebro delta, Spain. Environ. Pollut. 104(3): 435-444. doi: 10.1016/S02697491(98)00169-9.

Mateo, R., Cadenas, R., Máñez, M., Guitart, R. 2001. Lead shot ingestion in two raptor species from Donana, Spain. Ecotoxicol. Environ. Saf. 48(1): 6-10. doi: 10.1006/eesa.2000.1996.

Mateo, R., Taggart, M., Meharg, A.A. 2003. Lead and arsenic in bones of birds of prey from Spain. Environ. Pollut. 126(1): 107-114. doi: 10.1016/S02697491(03)00055-1.

Mateo, R., Green, A.J., Lefranc, H., Baos, R., Figuerola, J. 2007. Lead poisoning in wild birds from southern Spain: a comparative study of wetland areas and species affected, and trends over time. Ecotoxicol. Environ. Saf. 66(1): 119-126. doi: doi:10.1016/j.ecoenv.2005.12.010.

Mateo, R., Sánchez-Barbudo, I.S., Camarero, P.R., Martínez, J.M. 2015. Risk assessment of bearded vulture (Gypaetus barbatus) exposure to topical 
965

966

967

968

969

970

971

972

973

974

975

976

977

978

979

980

981

982

antiparasitics used in livestock within an ecotoxicovigilance framework. Sci. Total Environ. 536: 704-712. doi: 10.1016/j.scitotenv.2015.07.109.

Moleón, M., Gil-Sánchez, J.M., Real, L., Sánchez-Zapata, J.A., Bautista, J., SánchezClemot, J.F. 2007. Non-breeding feeding ecology of territorial Bonelli's eagles Hieraaetus fasciatus in the Iberian Peninsula. Ardeola 54(1): 135-143.

Monteiro, L.R., Furness, R.W. 1995. Seabirds as monitors of mercury in the marine environment. Water Air Soil Poll. 80(1): 851-870. doi: 10.1007/BF01189736.

Monteiro, L.R., Granadeiro, J.P., Furness, R.W. 1998. Relationship between mercury levels and diet in Azores seabirds. Mar. Ecol.-Prog. Ser. 166: 259-265. doi: $10.3354 /$ meps 166259 .

Moreno-Opo, R., Arredondo, A., Francisco, G. 2010. Foraging range and diet of cinereous vulture Aegypius monachus using livestock resources in central Spain. Ardeola 57(1): 111-119.

Moreno-Opo, R., Trujillano, A., Arredondo, A., González, L.M., Margalida, A. 2015. Manipulating size, amount and appearance of food inputs to optimize supplementary feeding programs for European vultures. Biol. Cons. 181: 27-35. doi: 10.1016/j.biocon.2014.10.022.

Movalli, P.A. 2000. Heavy metal and other residues in feathers of laggar falcon Falco biarmicus jugger from six districts of Pakistan. Environ. Pollut. 109(2): 267-275. doi: 10.1016/S0269-7491(99)00258-4.

Naccari, C., Cristani, M., Cimino, F., Arcoraci, T., Trombetta, D. 2009. Common buzzards (Buteo buteo) bio-indicators of heavy metals pollution in Sicily (Italy). Environ. Int. 35(3): 594-598. doi: 10.1016/j.envint.2008.11.002. 
988 National Research Council (US). Committee on Animals as Monitors 989 of Environmental Hazards. 1991. Animals as Sentinels of Environmental Health $990 \quad$ Hazards. National Academies Press (US), Washington (DC).

991 Negro, J.J., Donázar, J.A, Hiraldo, F., Hernández, L.M., Fernández, M.A. 1993. 992 Organochlorine and heavy metal contamination in non-viable eggs and its relation 993 to breeding success in a Spanish population of Lesser Kestrels (Falco naumanni). 994 Environ. Pollut. 82(2): 201-205. doi: 10.1016/0269-7491(93)90118-8.

995 Newton, I., Wyllie, I., Asher, A. 1993. Long-term trends in organochlorine and mercury 996 997 residues in some predatory birds in Britain. Environ. Pollut 79(2): 143-151. doi: 10.1016/0269-7491(93)90064-U.

998 999 1000 1001 1002 1003 1004 1005 1006 1007 1008 1009 1010 1011
Ortego, J., Jiménez, M., Díaz, M., Rodríguez, R.C. 2006. Mercury in feathers of nestling eagle owls, Bubo bubo L., and muscle of their main prey species in Toledo Province, Central Spain. Bull. Environ. Contam. Toxicol. 76(4): 648-655. doi: 10.1007/s00128-006-0969-z.

Ortiz-Santaliestra, M.E., Resano-Mayor, J., Hernández-Matías, A., Rodríguez-Estival, J., Camarero, P.R., Moleón, M., Real, J., Mateo, R. 2015. Pollutant accumulation patterns in nestlings of an avian top predator: biochemical and metabolic effects. Sci. Total Environ. 538: 692-702. doi: 10.1016/j.scitotenv.2015.08.053.

Pacyna, J.M., Pacyna, E.G. 2001. An assessment of global and regional emissions of trace metals to the atmosphere from anthropogenic sources worldwide. Environ. Rev. 9(4): 269-298. doi: 10.1139/a01-012.

Pain, D.J., Meharg, A.A., Ferrer, M, Taggart, M, Penteriani, V. 2005. Lead concentrations in bones and feathers of the globally threatened Spanish Imperial Eagle. Biol. Cons. 121(4): 603-610. doi: 10.1016/j.biocon.2004.06.012. 
1012 Palma, L., Beja, P., Tavares, P.C., Monteiro, L.R. 2005. Spatial variation of mercury 1015

1016

1017

1018

1019

1020

1021

1022

1023

1024

1025

1026

1027

1028

1029

1030

1031

1032

1033

1034
1013 levels in nesting Bonelli's eagles from Southwest Portugal: effects of diet 1014 composition and prey contamination. Environ. Pollut. 134(3): 549-557. doi: 10.1016/j.envpol.2004.05.017.

Pérez-Granados, C. 2010. Diet of adult Lesser kestrel Falco naumanni during the breeding season in Central Spain. Ardeola 57(2): 443-448.

Pérez-López, M., Hermoso de Mendoza, M., López Beceiro, A., Soler Rodríguez, F. 2008. Heavy metal (Cd, Pb, Zn) and metalloid (As) content in raptor species from Galicia (NW Spain). Ecotoxicol Environ Saf. 70(1): 154-162. doi: 10.1016/j.ecoenv.2007.04.016.

Petronillo, J.M.S., Vingada, J.V. 2002. First data on feeding ecology of Goshawk Accipiter gentilis during the breeding season in the natura 2000 site Dunas de Mira, Gândara e Gafanhas (Beira Litoral, Portugal). Airo. 12: 11-16.

Rodriguez-Ramos, J., Gutierrez, V., Höfle, U., Mateo, R., Monsalve, L., Crespo, E., Blanco, J.M. 2009. Lead in Griffon and Cinereous Vultures in Central Spain: Correlations between clinical signs and blood lead levels. Extended abstract In Ingestion of Lead from Spent Ammunition: Implications for Wildlife and Humans. Edited by R.T. Watson, M. Fuller, M. Pokras, W.G. Hunt. The Peregrine Fund, Boise, Idaho, USA.

Rodriguez-Ramos, J., Höfle, U., Mateo, R., Nicolas de Francisco, O., Abbott, R., Acevedo, P., Blanco, J.M. 2011. Assessment of lead exposure in Spanish imperial eagle (Aquila adalberti) from spent ammunition in central Spain. Ecotoxicology. 20(4): 670-681. doi: 10.1007/s10646-011-0607-3. 
1035 Sánchez, R., Margalida, A., González, L.M., Oria, J. 2008. Biases in diet sampling 1036 methods in the Spanish Imperial Eagle Aquila adalberti. Ornis Fennica 85: 82-89. 1037 Sánchez-Zapata, J.A., Eguía, S., Blázquez, M., Moleón, M., Francisco, B. 2010. 1038 Unexpected role of ungulate carcasses in the diet of Golden Eagles Aquila 1039 chrysaetos in Mediterranean mountains. Bird Study. 57(3): 352-360. doi: 1040 $10.1080 / 00063651003674946$.

1041

1042

1043

1044

1045

1046

1047

1048

1049

1050

1051

1052

1053

1054

1055

1056

1057

1058

Scheuhammer, A.M. 1987. The chronic toxicity of aluminium, cadmium, mercury, and lead in birds: a review. Environ. Pollut. 46(4): 263-295. doi: 10.1016/02697491(87)90173-4.

Scheuhammer, A.M., Meyer, M.W., Sandheinrich, M.B., Murray, M.W. 2007. Effects of environmental methylmercury on the health of wild birds, mammals, and fish. Ambio. 36(1): 12-18. doi: 10.1579/0044-7447(2007)36[12:EOEMOT]2.0.CO;2.

Shi, H., Shi, X., Liu, K.J. 2004. Oxidative mechanism of arsenic toxicity and carcinogenesis. Mol. Cell. Biochem. 255(1-2): 67-78. doi: 10.1023/B:MCBI.0000007262.26044.e8.

Shlosberg, A., Rumbeiha, W.K., Lublin, A., Kannan, K. 2011. A database of avian blood spot examinations for exposure of wild birds to environmental toxicants: the DABSE biomonitoring project. J. Environ. Monit. 13(6): 1547-1558. doi: $10.1039 / \mathrm{c} 0 \mathrm{em} 00754 \mathrm{~d}$.

Siverio, M., Rodríguez, B., Rodríguez, A., Siverio, F. 2011. Inter-insular variation of the diet of osprey Pandion haliaetus in the Canarian archipelago. Wildl. Biol. 17: 240-247. doi: 10.2981/10-004.

Stankovic, D., Manojlovic, D., Roglic, G., Kostic-Rajacic, S., Andjelkovic, I., Dojcinovic, B., Mutic, J. 2011. Simultaneous Determination of Pb and Cd Traces 
1059

1060

1061

1062

1063

1064

1065

1066

1067

1068

1069

1070

1071

1072

1073

1074

1075

1076

1077

1078

1079

1080

1081

1082

in Water Samples by Anodic Stripping Voltammetry Using a Modified GC Electrode. Electroanalysis. 23(8): 1928-1933. doi: 10.1002/elan.201100189.

Tapia, L., Domínguez, J., Romeu, M. 2007. Diet of Common buzzard (Buteo buteo) (Linnaeus, 1758) in an area of Northwestern Spain as assessed by direct observation from blinds. Nova Acta Ci Compostelana, Secc Biol. 16: 145-149.

Tartu, S., Goutte, A., Bustamante, P., Angelier, F., Moe, B., Clement-Chastel, C., Bech, C., Gabrielsen, G.W., Bustnes, J.O., Chastel, O. 2013. To breed or not to breed: endocrine response to mercury contamination by an Arctic seabird. Biol. Lett. 9(4): 1-4. doi: 10.1098/rsbl.2013.0317.

Thomas, R. 2001. A Beginner's Guide to ICP-MS, Part I. Spectroscopy. 16(4): 38-42.

Thompson, D.R. 1996. Mercury in birds and terrestrial mammals. In Environmental contaminants in wildlife: interpreting tissue concentrations, $1^{\text {st }}$ edn. Edited by W.N. Beyer, G.H. Heinz, A.W. Redmon-Norwood. Lewis, Boca Raton, pp. 341353.

Tomé, R., Catry, P., Bloise, C., Korpimäki, E. 2008. Breeding density and sucess, and diet composition of Little owls Athene noctua in steppe-like habitats in Portugal. Ornis Fennica. 85: 22-32.

Uthus, E.O. 1992. Evidence for arsenic essentiality. Environ. Geochem. Health. 14(2): 55-58. doi: 10.1007/BF01783629.

Villarán Adánez, A. 2000. Análisis comparativo de la dieta de ambos sexos en el Cárabo comun Strix aluco en la Península Ibérica. Ardeola. 47(2): 203-213.

Viñuela, J., Veiga, J.P. 1992. Importance of rabbits in the diet and reproductive success of Black Kites in southwestern Spain. Ornis Scandinavica. 23(2): 132-118. doi: $10.2307 / 3676440$. 
1083 Wolfe M.F., Schwarzbach, S, Sulaiman, R.A. 1998. Effects of mercury on wildlife: A 1084 comprehensive review. Environ. Toxicol. Chem. 17(2): 146-160. doi: $1085 \quad 10.1002 /$ etc. 5620170203.

1086 Zolfaghari, G., Esmaili-Sari, A., Ghasempouri, S.M., Kiabi, B.H. 2007. Examination of 1087 mercury concentration in the feathers of 18 species of birds in southwest Iran. 1088 Environ. Res. 104(2): 258-265. doi: 10.1016/j.envres.2006.12.002.

1089 
1090 Table 1. Main characteristics (trophic position, diet, conservation status and migratory habits) of the raptor species breeding in Portugal and

1091 Spain, specifying which ones were used for monitoring purposes of metals and the total number of analysed individuals.

\begin{tabular}{|c|c|c|c|c|c|c|c|}
\hline Common name & Scientific name & $\begin{array}{l}\text { Trophic position } \\
\text { (Most important prey) }\end{array}$ & \multicolumn{2}{|c|}{$\begin{array}{c}\text { Conservation } \\
\text { status }\end{array}$} & $\begin{array}{l}\text { Migratory } \\
\text { habits }\end{array}$ & $\begin{array}{l}\text { Total number } \\
\text { of analysed } \\
\text { individuals }\end{array}$ & References \\
\hline \multicolumn{8}{|c|}{ Accipitridae Family } \\
\hline $\begin{array}{l}\text { Northern } \\
\text { goshawk }\end{array}$ & $\begin{array}{l}\text { Accipiter } \\
\text { gentilis }\end{array}$ & $\begin{array}{l}\text { Bird and mammal predator (Red- } \\
\text { legged partridge, Domestic pigeon, } \\
\text { European rabbit) (Mañosa 1994; } \\
\text { Petronillo and Vingada 2002; Catry et } \\
\text { al. 2010) }\end{array}$ & VU & $\mathrm{LC}$ & Resident & 117 & $\begin{array}{l}\text { Hernández et al. 1986; Mateo et al. } \\
\text { 2003; Martínez-López et al. 2004, } \\
\text { 2005; Hermoso de Mendoza et al. } \\
\text { 2006; Pérez-López et al. 2008; } \\
\text { Castro et al. 2011; Debén et al. } \\
\text { 2012; Martínez et al. } 2012\end{array}$ \\
\hline $\begin{array}{l}\text { Eurasian } \\
\text { sparrowhawk }\end{array}$ & Accipiter nisus & $\begin{array}{l}\text { Bird predator (Passeriformes) (Mañosa } \\
\text { and Oro 1991; Catry et al. 2010) }\end{array}$ & $\mathrm{LC}$ & $\begin{array}{l}\mathrm{LC} / \\
\mathrm{VU}\end{array}$ & Resident & 22 & $\begin{array}{l}\text { García-Fernández et al. 1995, } \\
\text { 1996; Hermoso de Mendoza et al. } \\
\text { 2006; Pérez-López et al. } 2008\end{array}$ \\
\hline $\begin{array}{l}\text { Cinereous } \\
\text { vulture }\end{array}$ & $\begin{array}{l}\text { Aegypius } \\
\text { monachus }\end{array}$ & $\begin{array}{l}\text { Carrion consumer (Livestock } \\
\text { carcasses) (Catry et al. 2010; Moreno- } \\
\text { Opo et al. 2010) }\end{array}$ & $\mathrm{CR}$ & VU & Resident & 18 & $\begin{array}{l}\text { Hernández et al. 1986; Hermoso de } \\
\text { Mendoza et al. 2006; Cardiel et al. } \\
2011\end{array}$ \\
\hline $\begin{array}{l}\text { Spanish } \\
\text { Imperial eagle }\end{array}$ & $\begin{array}{l}\text { Aquila } \\
\text { adalberti } \\
\text { (heliaca) }\end{array}$ & $\begin{array}{l}\text { Bird and mammal predator (European } \\
\text { rabbit) (Sánchez et al. 2008; Catry et } \\
\text { al. 2010) }\end{array}$ & $\mathrm{CR}$ & EN & Resident & 257 & $\begin{array}{l}\text { González et al. 1984; Hernández et } \\
\text { al. 1986, 1988a; González and } \\
\text { Hiraldo 1988; Mateo et al. 2003; } \\
\text { Pain et al. 2005; Rodriguez-Ramos } \\
\text { et al. } 2011\end{array}$ \\
\hline Golden eagle & $\begin{array}{l}\text { Aquila } \\
\text { chrysaetos }\end{array}$ & $\begin{array}{l}\text { Bird and mammal predator/Carrion } \\
\text { consumer (European rabbit) (Catry et } \\
\text { al. 2010; Sánchez-Zapata et al. 2010) }\end{array}$ & EN & NT & Resident & 8 & $\begin{array}{l}\text { Hernández et al. 1988b; Cerradelo } \\
\text { et al. 1992; García-Fernández et al. } \\
\text { 1996; Mateo et al. } 2003\end{array}$ \\
\hline $\begin{array}{l}\text { Common } \\
\text { buzzard }\end{array}$ & Buteo buteo & $\begin{array}{l}\text { Bird and mammal predator (Small } \\
\text { mammals) (Mañosa and Cordero 1992; } \\
\text { Tapia et al. 2007; Catry et al. 2010) }\end{array}$ & $\mathrm{LC}$ & $\mathrm{LC}$ & Resident & 428 & $\begin{array}{l}\text { Hernández et al. 1988b; García- } \\
\text { Fernández et al. 1995, 1996, 1997; } \\
\text { Mateo et al. 2003; Martínez-López } \\
\text { et al. 2004, 2005; Hermoso de } \\
\text { Mendoza et al. 2006; Pérez-López } \\
\text { et al. 2008; Castro et al. 2011; } \\
\text { Martínez et al. 2012; Carneiro et } \\
\text { al. } 2014\end{array}$ \\
\hline
\end{tabular}


1092 Table 1. (Continued) Main characteristics (trophic position, diet, conservation status and migratory habits) of the raptor species breeding in

1093 Portugal and Spain, specifying which ones were used for monitoring purposes of metals and the total number of analysed individuals.

\begin{tabular}{|c|c|c|c|c|c|c|c|}
\hline \multirow[t]{2}{*}{ Common name } & \multirow[t]{2}{*}{ Scientific name } & \multirow{2}{*}{$\begin{array}{l}\text { Trophic position } \\
\text { (Most important prey) }\end{array}$} & \multicolumn{2}{|c|}{$\begin{array}{c}\text { Conservation } \\
\text { status } \\
\end{array}$} & \multirow{2}{*}{$\begin{array}{l}\text { Migratory } \\
\text { habits }\end{array}$} & \multirow{2}{*}{$\begin{array}{l}\text { Total number } \\
\text { of analysed } \\
\text { individuals }\end{array}$} & \multirow[t]{2}{*}{ References } \\
\hline & & & PT & $\mathbf{S P}$ & & & \\
\hline \multicolumn{8}{|c|}{ Accipitridae Family } \\
\hline $\begin{array}{l}\text { Short-toed } \\
\text { Eagle }\end{array}$ & $\begin{array}{l}\text { Circaetus } \\
\text { gallicus }\end{array}$ & $\begin{array}{l}\text { Predator (Reptiles: snakes and lizards) } \\
\text { (Gil and Pleguezuelos 2001; Catry et } \\
\text { al. 2010) }\end{array}$ & NT & LC & $\begin{array}{l}\text { Reproductive/ } \\
\text { Migratory }\end{array}$ & 3 & García-Fernández et al. 1996 \\
\hline Marsh harrier & $\begin{array}{l}\text { Circus } \\
\text { aeruginosus }\end{array}$ & $\begin{array}{l}\text { Bird and mammal predator (Small } \\
\text { mammals and birds) (Catry et al. 2010; } \\
\text { Cardador et al. 2012) }\end{array}$ & VU & $\mathrm{LC}$ & $\begin{array}{l}\text { Resident/ } \\
\text { Visitor }\end{array}$ & 79 & $\begin{array}{l}\text { Hernández et al. 1986; Mateo et al. } \\
\text { 1999; Alvárez et al. } 2013\end{array}$ \\
\hline Hen harrier & Circus cyaneus & $\begin{array}{l}\text { Bird and mammal predator } \\
\text { (Lagomorphs and birds)(García and } \\
\text { Arroyo 2005; Catry et al. 2010) }\end{array}$ & $\begin{array}{l}\mathrm{CR} / \\
\mathrm{VU}\end{array}$ & $\mathrm{LC}$ & $\begin{array}{l}\text { Resident/ } \\
\text { Visitor }\end{array}$ & - & - \\
\hline $\begin{array}{l}\text { Montagu's } \\
\text { harrier }\end{array}$ & $\begin{array}{l}\text { Circus } \\
\text { pygargus }\end{array}$ & $\begin{array}{l}\text { Predator (Lagomorphs, birds, insects) } \\
\text { (Arroyo 1997; Catry et al. 2010) }\end{array}$ & EN & VU & $\begin{array}{l}\text { Reproductive } \\
\text { Migratory }\end{array}$ & 10 & $\begin{array}{l}\text { García-Fernández et al. 1996; } \\
\text { Hermoso de Mendoza et al. } 2006\end{array}$ \\
\hline $\begin{array}{l}\text { Black-winged } \\
\text { kite }\end{array}$ & $\begin{array}{l}\text { Elanus } \\
\text { caeruleus }\end{array}$ & $\begin{array}{l}\text { Predator (Small mammals, birds, } \\
\text { reptiles, insects)(Catry et al. 2010) }\end{array}$ & NT & NT & Resident & - & 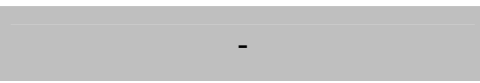 \\
\hline $\begin{array}{l}\text { Bearded } \\
\text { vulture }\end{array}$ & $\begin{array}{l}\text { Gypaetus } \\
\text { barbatus }\end{array}$ & $\begin{array}{l}\text { Carrion consumer (Bones of wild and } \\
\text { domestic ungulates) (Margalida et al. } \\
\text { 2005, 2007; Hernández and Margalida } \\
\text { 2009) }\end{array}$ & $\mathrm{RE}$ & $\mathrm{EN}$ & Resident & 136 & $\begin{array}{l}\text { Hernández and Margalida 2009; } \\
\text { Mateo et al. } 2015\end{array}$ \\
\hline $\begin{array}{l}\text { Griffon } \\
\text { vulture }\end{array}$ & Gyps fulvus & $\begin{array}{l}\text { Carrion consumer (Wild and domestic } \\
\text { ungulates) (Donázar 1993; Catry et al. } \\
\text { 2010; Donázar et al. 2010; Moreno- } \\
\text { Opo et al. 2015) }\end{array}$ & NT & $\mathrm{LC}$ & Resident & 245 & $\begin{array}{l}\text { García-Fernández et al. 1995, } \\
\text { 2005b; Mateo et al. 2003; Cardiel } \\
\text { et al. 2011; Espín et al. 2014a; } \\
\text { Carneiro et al. } 2015\end{array}$ \\
\hline Bonelli's eagle & $\begin{array}{l}\text { Hieraaetus } \\
\text { fasciatus }\end{array}$ & $\begin{array}{l}\text { Bird and mammal predator (Rabbits, } \\
\text { pigeons, partridges) (Moleón et al. } \\
\text { 2007; Catry et al. 2010) }\end{array}$ & $\mathrm{EN}$ & $\mathrm{EN}$ & Resident & 154 & $\begin{array}{l}\text { García-Fernández et al. 1995, } \\
\text { 1996; Mateo et al. 2003; Palma et } \\
\text { al. 2005; Figueira et al. 2009; } \\
\text { Ortiz-Santaliestra et al. } 2015\end{array}$ \\
\hline Booted eagle & $\begin{array}{l}\text { Hieraaetus } \\
\text { pennatus }\end{array}$ & $\begin{array}{l}\text { Bird and mammal predator (Songbirds) } \\
\text { (García Dios 2006; Catry et al. 2010) }\end{array}$ & NT & $\mathrm{LC}$ & $\begin{array}{l}\text { Reproductive } \\
\text { Migratory }\end{array}$ & 144 & $\begin{array}{l}\text { González et al. 1984; Hernández et } \\
\text { al. 1988b; García-Fernández et al. } \\
\text { 1995, 1996; Mateo et al. 2003; } \\
\text { Martínez-López et al. 2004, 2005 }\end{array}$ \\
\hline
\end{tabular}


1094 Table 1. (Continued) Main characteristics (trophic position, diet, conservation status and migratory habits) of the raptor species breeding in

1095 Portugal and Spain, specifying which ones were used for monitoring purposes of metals and the total number of analysed individuals.

\begin{tabular}{|c|c|c|c|c|c|c|c|}
\hline \multirow[t]{2}{*}{ Common name } & \multirow[t]{2}{*}{ Scientific name } & \multirow{2}{*}{$\begin{array}{l}\text { Trophic position } \\
\text { (Most important prey) }\end{array}$} & \multicolumn{2}{|c|}{$\begin{array}{c}\text { Conservation } \\
\text { status }\end{array}$} & \multirow{2}{*}{$\begin{array}{l}\text { Migratory } \\
\text { habits }\end{array}$} & \multirow{2}{*}{$\begin{array}{l}\text { Total number } \\
\text { of analysed } \\
\text { individuals }\end{array}$} & \multirow[t]{2}{*}{ References } \\
\hline & & & PT & SP & & & \\
\hline \multicolumn{8}{|c|}{ Accipitridae Family } \\
\hline Black kite & Milvus migrans & $\begin{array}{l}\text { Predator/Carrion consumer (European } \\
\text { rabbits, birds, fish, carrion) (Viñuela } \\
\text { and Veiga 1992; Catry et al. 2010) }\end{array}$ & $\mathrm{LC}$ & LC & $\begin{array}{l}\text { Reproductive } \\
\text { Migratory }\end{array}$ & 428 & $\begin{array}{l}\text { González et al. 1984; Hernández et } \\
\text { al. 1986, 1988b; García-Fernández } \\
\text { et al. 1996; Benito et al. 1999; } \\
\text { Blanco et al. 2003; Mateo et al. } \\
2003 \text {; Baos et al. 2006a, 2006b; } \\
\text { Cardiel et al. 2011; Alvárez et al. } \\
2013\end{array}$ \\
\hline Red kite & Milvus milvus & $\begin{array}{l}\text { Predator/Carrion consumer (Small } \\
\text { mammals, birds, fish, carrion) (García } \\
\text { et al. 1998; Catry et al. 2010) }\end{array}$ & CR & EN & $\begin{array}{l}\text { Resident/ } \\
\text { Visitor }\end{array}$ & 37 & $\begin{array}{l}\text { González et al. 1984; Mateo et al. } \\
\text { 2003; Hermoso de Mendoza et al. } \\
\text { 2006; Cardiel et al. } 2011\end{array}$ \\
\hline $\begin{array}{l}\text { Egyptian } \\
\text { vulture }\end{array}$ & $\begin{array}{l}\text { Neophron } \\
\text { percnopterus }\end{array}$ & $\begin{array}{l}\text { Carrion consumer (Carcasses of } \\
\text { mammals and birds, garbage dumps) } \\
\text { (Donázar et al. 2002; Hidalgo et al. } \\
\text { 2005; Margalida et al. 2012) }\end{array}$ & EN & EN & $\begin{array}{l}\text { Reproductive } \\
\text { Migratory }\end{array}$ & 234 & $\begin{array}{l}\text { Donázar et al. 2002; Gangoso et al. } \\
2009\end{array}$ \\
\hline Honey buzzard & Pernis apivorus & $\begin{array}{l}\text { Invertebrate predator (Larvae of } \\
\text { hymenopterans) (Catry et al. 2010) }\end{array}$ & VU & $\mathrm{LC}$ & $\begin{array}{l}\text { Reproductive } \\
\text { Migratory }\end{array}$ & - & - \\
\hline \multicolumn{8}{|c|}{ Pandionidae family } \\
\hline Osprey & $\begin{array}{l}\text { Pandion } \\
\text { haliaetus }\end{array}$ & $\begin{array}{l}\text { Fish predator (Fish) (Catry et al. 2010; } \\
\text { Siverio et al. 2011) }\end{array}$ & $\mathrm{CR}$ & $\mathrm{EN}$ & $\begin{array}{l}\text { Resident/ } \\
\text { Visitor }\end{array}$ & - & - \\
\hline \multicolumn{8}{|c|}{ Falconidae family } \\
\hline $\begin{array}{l}\text { Eleonora's } \\
\text { falcon }\end{array}$ & Falco eleonarae & $\begin{array}{l}\text { Predator (Insects) (Madroño et al. } \\
\text { 2004) }\end{array}$ & $\mathrm{RE}$ & NT & $\begin{array}{l}\text { Reproductive } \\
\text { migratory }\end{array}$ & - & - \\
\hline Lesser kestrel & Falco naumanni & $\begin{array}{l}\text { Predator (Insects) (Madroño et al. } \\
\text { 2004; Catry et al. 2010; Pérez- } \\
\text { Granados 2010) }\end{array}$ & VU & VU & $\begin{array}{l}\text { Reproductive } \\
\text { Migratory }\end{array}$ & 41 & Negro et al. 1993 \\
\hline Hobby & Falco subbuteo & $\begin{array}{l}\text { Bird and invertebrate predator (Small } \\
\text { birds and insects) (Madroño et al. } \\
\text { 2004; Catry et al. 2010) }\end{array}$ & $\mathrm{VU}$ & NT & $\begin{array}{l}\text { Reproductive } \\
\text { Migratory }\end{array}$ & 7 & González et al. 1984 \\
\hline
\end{tabular}


1096 Table 1. (Continued) Main characteristics (trophic position, diet, conservation status and migratory habits) of the raptor species breeding in

1097 Portugal and Spain, specifying which ones were used for monitoring purposes of metals and the total number of analysed individuals.

\begin{tabular}{|c|c|c|c|c|c|c|c|}
\hline \multirow[t]{2}{*}{ Common name } & \multirow[t]{2}{*}{ Scientific name } & \multirow{2}{*}{$\begin{array}{l}\text { Trophic position } \\
\text { (Most important prey) }\end{array}$} & \multicolumn{2}{|c|}{$\begin{array}{c}\text { Conservation } \\
\text { status } \\
\end{array}$} & \multirow{2}{*}{$\begin{array}{l}\text { Migratory } \\
\text { habits }\end{array}$} & \multirow{2}{*}{$\begin{array}{l}\text { Total number } \\
\text { of individuals } \\
\text { analysed }\end{array}$} & \multirow[t]{2}{*}{ References } \\
\hline & & & PT & SP & & & \\
\hline \multicolumn{8}{|l|}{ Falconidae family } \\
\hline Barbary falcon & $\begin{array}{l}\text { Falco } \\
\text { pelegrinoides }\end{array}$ & $\begin{array}{l}\text { Bird predator (Domestic pigeon) } \\
\text { (Madroño et al. 2004) }\end{array}$ & I & $\mathrm{EN}$ & Resident & - & - \\
\hline $\begin{array}{l}\text { Peregrine } \\
\text { falcon }\end{array}$ & $\begin{array}{l}\text { Falco } \\
\text { peregrinus }\end{array}$ & $\begin{array}{l}\text { Bird predator (Domestic pigeon) } \\
\text { (López-López et al. 2009) }\end{array}$ & VU & $\mathrm{LC}$ & Resident & 18 & $\begin{array}{l}\text { Hernández et al. 1988b; Mateo et } \\
\text { al. 2003; Alvárez et al. } 2013\end{array}$ \\
\hline $\begin{array}{l}\text { Common } \\
\text { kestrel }\end{array}$ & $\begin{array}{l}\text { Falco } \\
\text { tinnunculus }\end{array}$ & $\begin{array}{l}\text { Predator (Insects, rodents, birds) (Gil- } \\
\text { Delgado et al. 1995; Catry et al. 2010) }\end{array}$ & LC & $\mathrm{LC}$ & Resident & 94 & $\begin{array}{l}\text { García-Fenández et al. 1995,1996, } \\
\text { 1997, 2005a; Hermoso de Mendoza } \\
\text { et al. 2006; Pérez-López et al. 2008; } \\
\text { Lourenço et al. } 2011\end{array}$ \\
\hline \multicolumn{8}{|l|}{ Strigidae family } \\
\hline $\begin{array}{l}\text { Tengmalm's } \\
\text { owl }\end{array}$ & $\begin{array}{l}\text { Aegolius } \\
\text { funereus }\end{array}$ & $\begin{array}{l}\text { Mammal predator (Voles) (Korpimaki } \\
\text { 1988) }\end{array}$ & - & NT & Resident & - & - \\
\hline $\begin{array}{l}\text { Short-eared } \\
\text { owl }\end{array}$ & Asio flammeus & $\begin{array}{l}\text { Bird and mammal predator' (Small } \\
\text { mammals, birds, insects) (Madroño et } \\
\text { al. 2004; Catry et al. 2010) }\end{array}$ & $\mathrm{EN}$ & NT & $\begin{array}{l}\text { Visitor/ } \\
\text { Reproductive }\end{array}$ & - & - \\
\hline $\begin{array}{l}\text { Long-eared } \\
\text { owl }\end{array}$ & Asio otus & $\begin{array}{l}\text { Mammal predator (Small mammals) } \\
\text { (Delibes et al. 1984; Catry et al. 2010) }\end{array}$ & $\mathrm{DD}$ & $\mathrm{LC}$ & Resident & 5 & $\begin{array}{l}\text { García-Fernández et al. 1996; } \\
\text { Pérez-López et al. } 2008\end{array}$ \\
\hline Little owl & Athene noctua & $\begin{array}{l}\text { Predator (Insects, small mammals) } \\
\text { (Delibes et al. 1984; Tomé et al. 2008; } \\
\text { Catry et al. 2010) }\end{array}$ & $\mathrm{LC}$ & $\mathrm{LC}$ & Resident & 52 & $\begin{array}{l}\text { García-Fernández et al. 1995, 1996, } \\
\text { 1997; Pérez-López et al. 2008; } \\
\text { Lourenço et al. } 2011\end{array}$ \\
\hline Eagle owl & Bubo bubo & $\begin{array}{l}\text { Bird and mammal predator (European } \\
\text { rabbit) (Catry et al. 2010; Gómez- } \\
\text { Ramírez et al. 2010) }\end{array}$ & NT & $\mathrm{LC}$ & Resident & 979 & $\begin{array}{l}\text { García-Fenández et al. 1995, 1996, } \\
\text { 1997; Mateo et al. 2003; Ortego et } \\
\text { al. 2006; Gómez-Ramírez et al. } \\
\text { 2010; Lourenço et al. 2011; Espín } \\
\text { et al. 2014b, 2014c }\end{array}$ \\
\hline Scops owl & Otus scops & Predator (Insects) (Catry et al. 2010) & $\mathrm{DD}$ & $\mathrm{LC}$ & $\begin{array}{l}\text { Reproductive } \\
\text { Migratory }\end{array}$ & 1 & García-Fernández et al. 1996 \\
\hline
\end{tabular}


1099 Table 1. (Continued) Main characteristics (trophic position, diet, conservation status and migratory habits) of the raptor species breeding in

1100 Portugal and Spain, specifying which ones were used for monitoring purposes of metals and the total number of analysed individuals.

\begin{tabular}{|c|c|c|c|c|c|c|c|}
\hline \multirow{2}{*}{ Common name } & \multirow{2}{*}{ Scientific name } & \multirow{2}{*}{$\begin{array}{l}\text { Trophic position } \\
\text { (Most important prey) }\end{array}$} & \multicolumn{2}{|c|}{$\begin{array}{c}\text { Conservation } \\
\text { status }\end{array}$} & \multirow{2}{*}{$\begin{array}{l}\text { Migratory } \\
\text { habits }\end{array}$} & \multirow{2}{*}{$\begin{array}{l}\text { Total number } \\
\text { of individuals } \\
\text { analysed }\end{array}$} & \multirow[t]{2}{*}{ References } \\
\hline & & & PT & SP & & & \\
\hline \multicolumn{8}{|l|}{ Strigidae family } \\
\hline Tawny owl & Strix aluco & $\begin{array}{l}\text { Predator (Invertebrates, rodents) } \\
\text { (Villarán Adánez 2000; Catry et al. } \\
\text { 2010) }\end{array}$ & $\mathrm{LC}$ & $\mathrm{LC}$ & Resident & 74 & $\begin{array}{l}\text { Pérez-López et al. 2008; Castro et } \\
\text { al. 2011; Lourenço et al. 2011; } \\
\text { Debén et al. } 2012\end{array}$ \\
\hline \multicolumn{8}{|l|}{ Tytonidae family } \\
\hline Barn owl & Tyto alba & $\begin{array}{l}\text { Predator (Rodents)(Gigirey et al. 2004; } \\
\text { Catry et al. 2010) }\end{array}$ & $\mathrm{LC}$ & $\mathrm{LC}$ & Resident & 33 & $\begin{array}{l}\text { García-Fernández et al. 1996; } \\
\text { Pérez-López et al. 2008; Lourenço } \\
\text { et al. } 2011\end{array}$ \\
\hline
\end{tabular}

1101 
Table 2. Sampling periods and bird species studied by each monitored area of Portugal and Spain.

\begin{tabular}{|c|c|c|}
\hline Areas & Sampling Periods & Species (n) \\
\hline North-west, Spain & $\begin{array}{l}\text { 1997-2005 (Castro et al. 2011) } \\
1999-2005^{\text {(Hermoso de Mendoza et al. 2006) }} \\
\text { 2001-2009 } \\
\text { (Martínez et al. 2012) } \\
\text { UP }^{*} \text { (Pérez-López et al. 2008; Debén et al. 2012) }\end{array}$ & $\begin{array}{l}\text { Common buzzard }(n=146) \text {, Tawny owl }(n=71) \text {, Northern } \\
\text { goshawk }(n=81) \text {, Barn owl }(n=16) \text {, Eurasian } \\
\text { sparrowhawk }(n=16) \text {, Bonelli's eagle }(n=11) \text {, Common } \\
\text { kestrel }(n=6) \text {, Long-eared owl }(n=4) \text {, Little owl }(n=3)\end{array}$ \\
\hline North-east, Spain & $\begin{array}{l}1990-1991^{\text {(Cerradelo et al. 1992) }} \\
1992-1995^{\text {(Mateo et al. 1999) }} \\
1998-2001^{\text {(Mateo et al. 2003)† }} \\
2002^{\text {(Gangoso et al. 2009) }} \\
2004-2013^{\text {(Mateo et al. 2015) }} \\
2008^{\text {(Hernández and Margalida 2009) }} \\
2010-2011^{\text {(Ortiz-Santaliestra et al. 2015) }} \\
2010-2012^{\text {(Carneiro et al. 2015) }}\end{array}$ & $\begin{array}{l}\text { Bearded vulture }(n=136) \text {, Bonelli's eagle }(n=85) \dagger \text {, } \\
\text { Common buzzard }(n=53) \dagger \text {, Griffon vulture }(n=52) \dagger \text {, } \\
\text { Marsh harrier }(n=47) \text {, Eagle owl }(n=21) \dagger \text {, Northern } \\
\text { goshawk }(n=9) \dagger \text {, Black kite }(n=8) \dagger \text {, Red kite }(n=6) \dagger \text {, } \\
\text { Booted eagle }(n=5) \dagger \text {, Egyptian vulture }(n=10) \text {, Peregrine } \\
\text { falcon }(n=4) \dagger, \text {, Golden eagle }(n=3) \dagger \text {, Spanish Imperial } \\
\text { eagle }(n=1) \dagger\end{array}$ \\
\hline West, Spain & $1999-2005^{\text {(Hermoso de Mendoza et al. 2006) }}$ & $\begin{array}{l}\text { Montagu's harrier }(n=8) \text {, Cinereous vulture }(n=6) \text {, } \\
\text { Griffon vulture }(n=5) \text {, Red kite }(n=5) \text {, Common buzzard } \\
(n=3)\end{array}$ \\
\hline Centre, Spain & $\begin{array}{l}1979-1984^{\text {(González and Hiraldo 1988) }} \\
1982-1985^{\text {(Hernández et al. 1986) }} \\
1985-1986^{\text {(Hernández et al. 1988b) }} \\
1986-1987^{\text {(Hernández et al. 1988a) }} \\
1997-2008^{\text {(Rodriguez-Ramos et al. 2011) }} \\
1998-2001^{\text {(Mateo et al. 2003)† }} \\
2002-2003^{\text {(Ortego et al. 2006) }} \\
2003-2004^{\text {(Gangoso et al. 2009) }} \\
2001^{\text {(Blanco et al. 2003) }}\end{array}$ & $\begin{array}{l}\text { Spanish Imperial eagle }(n=127) \dagger \text {, Black kite }(n=91) \dagger \text {, } \\
\text { Common buzzard }(n=56) \dagger \text {, Eagle owl }(n=53) \dagger \text {, Egyptian } \\
\text { vulture }(n=19) \text {, Marsh harrier }(n=17) \text {, Northern goshawk } \\
(n=11) \dagger \text {, Booted eagle }(n=9) \dagger \text {, Peregrine falcon }(n=8) \dagger \text {, } \\
\text { Red kite }(n=6) \dagger \text {, Golden eagle }(n=4) \dagger \text {, Bonelli's eagle } \\
(n=3) \dagger \text {, Griffon vulture }(n=2) \dagger\end{array}$ \\
\hline East, Spain & $2011^{\text {(Espín et al. 2014a) }}$ & Griffon vulture $(n=66)$ \\
\hline South, Spain & $\begin{array}{l}1980-1999^{\text {(Pain et al. 2005) }} \\
1988-1991^{\text {(Negro et al. 1993) }} \\
2010-2011^{\text {(Ortiz-Santaliestra et al. 2015) }}\end{array}$ & $\begin{array}{l}\text { Spanish Imperial eagle }(n=75) \text {, Lesser kestrel }(n=41) \text {, } \\
\text { Bonelli's Eagle }(n=30)\end{array}$ \\
\hline South-west, Spain & $\begin{array}{l}\text { 1980-1983 }{ }^{\text {(González et al. 1984) }} \\
1982-1985^{(\text {Hernández et al. 1986) }} \\
1985-1986^{\text {(Hernández et al. 1988b) }} \\
1986-1987^{\text {(Hernández et al. 1988a) }} \\
1999^{\text {(Benito et al. 1999) }} \\
1999-2000^{\text {(Alvárez et al. 2013) }} \\
1999,2001-2003^{\text {(Baos et al. 2006a) }} \\
1999-2002^{\text {(Baos et al. 2006b) }} \\
2003^{\text {(Gangoso et al. 2009) }} \\
2003-2007^{\text {(Lourenço et al. 2011)† }}\end{array}$ & $\begin{array}{l}\text { Black kite }(n=318) \text {, Spanish Imperial eagle }(n=54) \text {, Eagle } \\
\text { owl }(n=30) \dagger \text {, Marsh harrier }(n=15) \text {, Red kite }(n=10) \text {, } \\
\text { Booted eagle }(n=7) \text {, Hobby }(n=7) \text {, Little owl }(n=7) \dagger \text {, } \\
\text { Barn owl }(n=6) \dagger \text {, Peregrine falcon }(n=6) \text {, Egyptian } \\
\text { vulture }(n=3) \text {, Common buzzard }(n=2) \text {, Tawny owl } \\
(n=1) \dagger\end{array}$ \\
\hline South-east, Spain & $\begin{array}{l}1993^{\text {(Garcia-Fernández et al. 1995, 1996) }} \\
1994^{\text {(García-Fernández et al. 1997) }} \\
1995-1997,2001^{\text {(García-Fernández et al. 2005a) }} \\
1999-2000^{(\text {Martínez-López et al. 2004, 2005) }} \\
2003^{\text {(García-Fernández et al. 2005b) }} \\
2003-2007^{\text {(Gomez-Ramirez et al. 2010) }} \\
2006-2012^{\text {(Espín et al. 2014c) }} \\
2011-2012^{\text {(Espín et al. 2014b) }}\end{array}$ & $\begin{array}{l}\text { Eagle owl }(n=844) \text {, Booted eagle }(n=123) \text {, Common } \\
\text { kestrel ( } n=87) \text {, Common buzzard }(n=43) \text {, Little owl } \\
(n=34) \text {, Griffon vulture }(n=29) \text {, Northern goshawk } \\
(n=16) \text {, Eurasian sparrowhawk }(n=6) \text {, Barn owl }(n=4) \text {, } \\
\text { Bonelli's eagle }(n=4) \text {, Short-toed eagle }(n=3) \text {, Black kite } \\
(n=2) \text {, Montagu's harrier }(n=2) \text {, Golden eagle }(n=1) \text {, } \\
\text { Long-eared owl }(n=1) \text {, Scops owl }(n=1)\end{array}$ \\
\hline $\begin{array}{c}\text { Balearic Islands, } \\
\text { Spain }\end{array}$ & 1982-1985 (Hernández et al. 1986) & Cinereous vulture $(\mathrm{n}=9)$ \\
\hline $\begin{array}{c}\text { Canary Islands, } \\
\text { Spain }\end{array}$ & $\begin{array}{l}1998-2001^{\text {(Donázar et al. 2002) }} \\
1999-2005^{\text {(Gangoso et al. 2009) }}\end{array}$ & Egyptian vulture $(\mathrm{n}=191)$ \\
\hline Portugal & $\begin{array}{l}1992-2001^{\text {(Palma et al. 2005; Figueira et al. 2009) }} \\
2003-2007^{\text {(Lourenço et al. 2011)† }} \\
2007-2012^{\text {(Carneiro et al. 2014, 2015) }}\end{array}$ & $\begin{array}{l}\text { Common buzzard }(\mathrm{n}=125) \text {, Griffon vulture }(\mathrm{n}=71) \text {, Eagle } \\
\text { owl }(\mathrm{n}=31)^{*} \text {, Bonelli's eagle }(\mathrm{n}=21) \text {, Little owl }(\mathrm{n}=8)^{*} \text {, } \\
\text { Barn owl }(\mathrm{n}=7)^{*} \text {, Tawny owl }(\mathrm{n}=2)^{*} \text {, Common kestrel } \\
(\mathrm{n}=1)\end{array}$ \\
\hline
\end{tabular}


1106 Table 2. (Continued) Sampling periods and bird species studied by each monitored area of

1107 Portugal and Spain.

1108

1109

*UP (unknown period), †The author does not provide the number of species collected in each area and thus an

1110 estimate (mean) was performed.

1111 NOTE: The author and their collaborators, Cardiel et al. 2011 does not specify the sampling area and period for the

1112 species Griffon vulture ( $n=20)$, Cinereous vulture $(n=3)$, Black kite $(n=9)$ and Red kite $(n=10)$. 
1113 Table 3. The metals and metalloids measured in each raptor species from Portugal and Spain per sample type and the total number (n) of the 1114 different samples analysed for each species.

\begin{tabular}{|c|c|c|c|c|c|c|c|}
\hline & Blood $(n=2087)$ & Liver $(n=594)$ & Kidney $(n=318)$ & Brain $(n=193)$ & Bone $(n=593)$ & Feathers $(n=884)$ & Eggs $(n=268)$ \\
\hline $\begin{array}{l}\text { Northern } \\
\text { goshawk }\end{array}$ & $\begin{array}{l}\mathbf{C d}^{\text {(Martínez-López et al. 2005) }} \\
\mathbf{P} \mathbf{b}^{\text {(Martínez-López et al. 2004) }} \\
(\mathrm{n}=6)\end{array}$ & $\begin{array}{l}\text { As }{ }^{\text {(Hermoso de Mendoza et al. }} \\
\text { 2006; Pérez-López et al. 2008) } \\
\mathbf{C d}^{\text {(Hermoso de Mendoza et al. }} \\
\text { 2006; Pérez-López et al. 2008; } \\
\text { Castro et al. 2011) } \\
\mathbf{H g}^{\text {(Castro et al. 2011) }} \\
\text { Pb }^{\text {(Hermoso de Mendoza et al. }} \\
\text { 2006; Pérez-López et al. 2008; } \\
\text { Castro et al. 2011) } \\
\mathbf{Z n}^{\text {(Hermoso de Mendoza et al. }} \\
\text { 2006; Pérez-López et al. 2008) } \\
\text { (n=22) }\end{array}$ & $\begin{array}{l}\mathbf{C d}^{\text {(Castro et al. 2011) }} \\
\mathbf{H g}^{(\text {Castro et al. 2011) }} \\
\mathbf{P b}^{(\text {Castro et al. 2011) }} \\
(\mathrm{n}=16)\end{array}$ & & $\begin{array}{l}\mathbf{A s}^{(\text {Mateo et al. 2003) }} \\
\mathbf{P b}^{(\text {Mateo et al. 2003) }} \\
(\mathrm{n}=18)\end{array}$ & $\begin{array}{l}\mathbf{C d}^{\text {(Martínez-López et al. 2005; }} \\
\text { Castro et al. 2011) } \\
\mathbf{H g}_{\text {et al. 2012) }}^{\text {(Castro et al. 2011; Martínez }} \\
\text { Pb }^{\text {(Martínez-López et al. 2004; }} \\
\text { Castro et al. 2011; Debén et al. } \\
\text { 2012) } \\
(\mathrm{n}=36)\end{array}$ & $\begin{array}{l}\mathbf{C} \mathbf{d}^{\text {(Hernández et al. 1986) }} \\
\mathbf{C} \mathbf{u}^{\text {(Hernández et al. 1986) }} \\
\mathbf{H g}{ }^{\text {Hernández et al. 1986) }} \\
\mathbf{P b}^{\text {(Hernández et al. 1986) }} \\
\mathbf{Z n}^{\text {(Hernández et al. 1986) }} \\
(\mathrm{n}=2)\end{array}$ \\
\hline $\begin{array}{l}\text { Eurasian } \\
\text { sparrowhawk }\end{array}$ & $\begin{array}{l}\mathbf{C d}^{(\text {García-Fernández et al. 1996) }} \\
(\mathrm{n}=1)\end{array}$ & 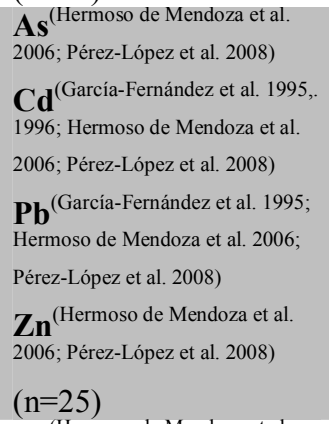 & $\begin{array}{l}\mathbf{C d}^{\text {(García-Fernández et al. 1995, }} \\
\text { 1996) } \\
\text { Pb }^{(\text {García-Fernández et al. 1995) }} \\
(\mathrm{n}=9)\end{array}$ & $\begin{array}{l}\text { Cd } \mathbf{d}^{\text {(García-Fernández et al. 1995, }} \\
\text { 1996) } \\
\text { Pb }^{\text {(Garcia-Fernández et al. 1995) }} \\
(\mathrm{n}=9)\end{array}$ & $\begin{array}{l}\mathbf{C d}^{\text {(García-Fernández et al. 1995, }} \\
\text { 1996) } \\
\text { Pb }^{\text {(García-Fernández et al. 1995) }} \\
(\mathrm{n}=9)\end{array}$ & & \\
\hline $\begin{array}{l}\text { Cinereous } \\
\text { vulture }\end{array}$ & & $\begin{array}{l}\text { As } \mathbf{s}^{\text {(Hermoso de Mendoza et al. }} \\
\mathbf{C d}^{\text {(Hermoso de Mendoza et al. }} \\
2006) \\
\mathbf{P b}^{\text {(Hermoso de Mendoza et al. }} \\
{ }_{2006)} \\
\mathbf{Z n}^{\text {(Hermoso de Mendoza et al. }} \\
(\mathrm{n}=6)\end{array}$ & & & $\begin{array}{l}\mathbf{P} \mathbf{b}^{(\text {Cardiel et al. 2011) }} \\
(\mathrm{n}=3)\end{array}$ & $\begin{array}{l}\mathbf{A l}^{(\text {Cardiel et al. 2011) }}, \\
\mathbf{P b}^{(\text {Cardiel et al. 2011) }} \\
(\mathrm{n}=3)\end{array}$ & $\begin{array}{l}\mathbf{C} \mathbf{d}^{\text {(Hernández et al. 1986) }} \\
\mathbf{C} \mathbf{u}^{\text {(Hernández et al. 1986) }} \\
\mathbf{H g}{ }^{\text {Hernández et al. 1986) }} \\
\mathbf{P b}^{\text {(Hernández et al. 1986) }} \\
\mathbf{Z} \mathbf{n}^{\text {(Hernández et al. 1986) }} \\
(\mathrm{n}=9)\end{array}$ \\
\hline
\end{tabular}


1115 Table 3. (Continued) The metals and metalloids measured in each raptor species from Portugal and Spain per sample type and the total number

1116 (n) of the different samples analysed for each species.

\begin{tabular}{|c|c|c|c|c|c|c|c|}
\hline & Blood $(n=2087)$ & Liver $(n=594)$ & Kidney (n=318) & Brain $(n=193)$ & Bone $(n=593)$ & Feathers $(n=884)$ & Eggs $(n=268)$ \\
\hline $\begin{array}{l}\text { Cinereous } \\
\text { vulture }\end{array}$ & & $\begin{array}{l}\mathbf{A s} \mathbf{s}^{\text {(Hermoso de Mendoza et al. }} \\
2006) \\
\mathbf{C d}^{\text {(Hermoso de Mendoza et al. }} \\
2006) \\
\mathbf{P b}^{\text {(Hermoso de Mendoza et al. }} \\
2006) \\
\mathbf{Z n}^{\text {(Hermoso de Mendoza et al. }} \\
2006) \\
(\mathrm{n}=6)\end{array}$ & & & $\begin{array}{l}\mathbf{P b}^{(\text {Cardiel et al. 2011) }} \\
(\mathrm{n}=3)\end{array}$ & $\begin{array}{l}\mathbf{A l}^{(\text {Cardiel et al. 2011) }} \\
\mathbf{P b}^{(\text {Cardiel et al. 2011) }} \\
(\mathrm{n}=3)\end{array}$ & $\begin{array}{l}\mathbf{C d}^{\text {(Hernández et al. 1986) }} \\
\mathbf{C u}^{\text {(Hernández et al. 1986) }} \\
\mathbf{H g}^{\text {(Hernández et al. 1986) }} \\
\mathbf{P b}^{\text {(Hernández et al. 1986) }} \\
\mathbf{Z n}^{\text {(Hernández et al. 1986) }} \\
(\mathrm{n}=9)\end{array}$ \\
\hline $\begin{array}{l}\text { Spanish } \\
\text { Imperial } \\
\text { eagle }\end{array}$ & & $\begin{array}{l}\mathbf{P b}^{(\text {Rodriguez-Ramos et al. 2011) }} \\
(\mathrm{n}=15)\end{array}$ & 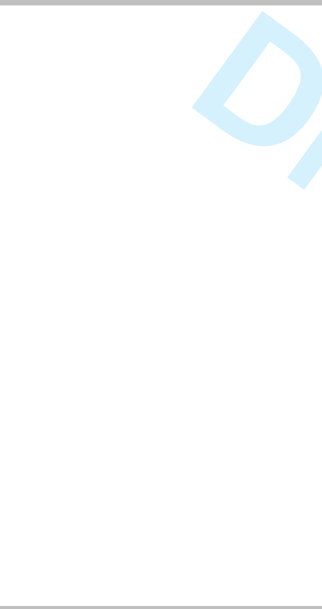 & 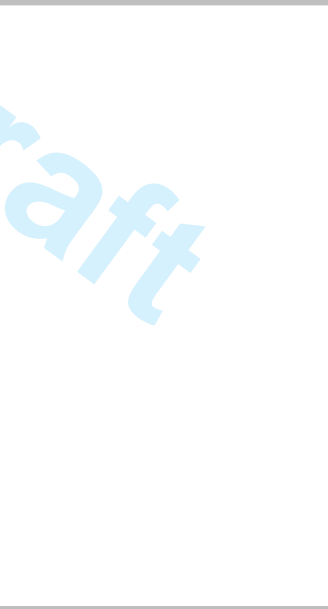 & $\begin{array}{l}\text { As } \mathbf{s}^{\text {(Mateo et al. 2003) }} \\
\text { Pb }^{\text {(Mateo et al. 2003; Pain et al. }} \\
2005 \text {; Rodriguez-Ramos et al. } \\
\text { 2011) } \\
(\mathrm{n}=90)\end{array}$ & $\begin{array}{l}\text { Pb }^{(\text {Pain et al. 2005; Rodriguez- }} \\
\text { Ramos et al. 2011) } \\
(\mathrm{n}=195)\end{array}$ & 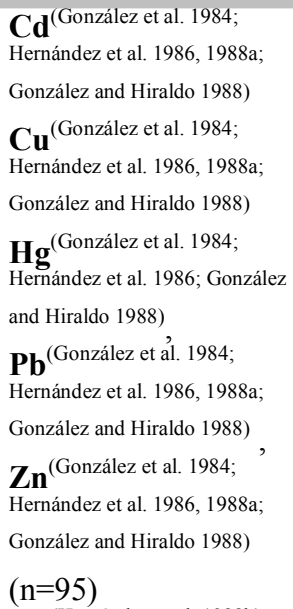 \\
\hline Golden eagle & $\begin{array}{l}\text { Cd }^{(\text {García-Fernández et al. 1996) }} \\
(n=1)\end{array}$ & $\begin{array}{l}\mathbf{C d}^{\text {(García-Fernández et al. 1996) }} \\
\mathbf{P b}^{\text {(Cerradelo et al. 1992) }} \\
(\mathrm{n}=4)\end{array}$ & $\begin{array}{l}\mathbf{C d}^{(\text {García-Fernández et al. 1996) }} \\
\mathbf{P b}^{(\text {Cerradelo et al. 1992) }} \\
(\mathrm{n}=4)\end{array}$ & $\begin{array}{l}\mathbf{C d}^{(\text {García-Fernández et al. 1996) }} \\
(\mathrm{n}=1)\end{array}$ & $\begin{array}{l}\text { As } \text { (Mateo et al. 2003) }^{\text {(García-Fernández et al. 1996) }} \\
\mathbf{C d}^{\text {(Mateo et al. 2003) }} \\
\mathbf{P b}^{\text {(Mat }} \\
(\mathrm{n}=4)\end{array}$ & & $\begin{array}{l}\mathbf{C} \mathbf{d}^{\text {(Hernández et al. 1988b) }} \\
\mathbf{C u}^{\text {(Hernández et al. 1988b) }} \\
\mathbf{H g}^{\text {(Hernández et al. 1988b) }} \\
\mathbf{P b}^{\text {(Hernández et al. 1988b) }} \\
\mathbf{Z n}^{\text {(Hernández et al. 1988b) }} \\
(\mathrm{n}=3)\end{array}$ \\
\hline
\end{tabular}


1118 Table 3. (Continued) The metals and metalloids measured in each raptor species from Portugal and Spain per sample type and the total number

1119 (n) of the different samples analysed for each species.

\begin{tabular}{|c|c|c|c|c|c|c|c|}
\hline & Blood $(n=2087)$ & Liver $(n=594)$ & Kidney $(n=318)$ & Brain $(n=193)$ & Bone $(n=593)$ & Feathers $(n=884)$ & Eggs $(n=268)$ \\
\hline $\begin{array}{l}\text { Common } \\
\text { buzzard }\end{array}$ & $\begin{array}{l}\mathbf{A s}^{(\text {Carneiro et al. 2014) }} \\
\mathbf{C d}^{\text {(García-Fernández et al. 1995, }} \\
\text { 1996; Martinez-López et al. 2005; } \\
\text { Carneiro et al. 2014) } \\
\mathbf{H g}^{\text {(Carneiro et al. 2014) }} \\
\text { Pb }^{\text {(García-Fernández et al. 1995, }} \\
\text { 1997; Martínez-López et al. 2004; } \\
\text { Carneiro et al. 2014) } \\
(\mathrm{n}=113)\end{array}$ & 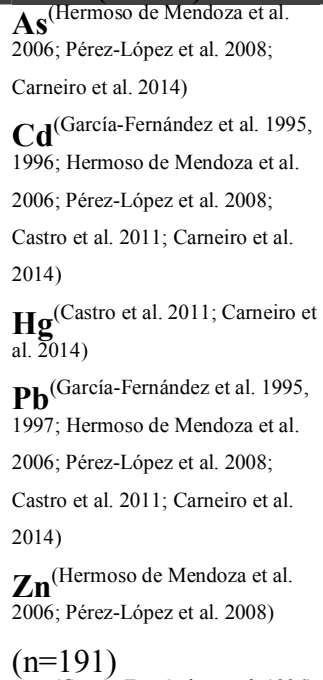 & 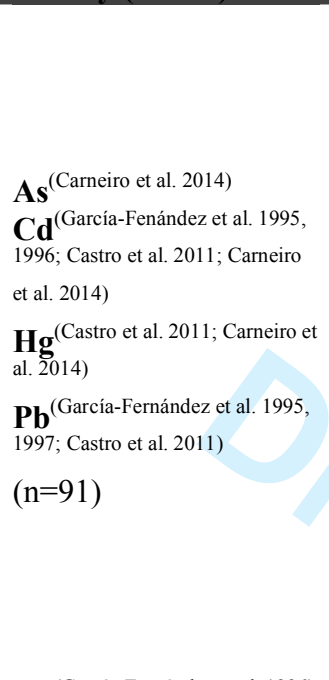 & $\begin{array}{l}\text { Cd } \mathbf{d}^{(\text {García-Fernández et al. 1995, }} \\
\mathbf{P b}^{(\text {García-Fernández et al. 1995, }} \\
1997) \\
(\mathrm{n}=17) \\
\end{array}$ & $\begin{array}{l}\mathbf{A s} \mathbf{s}^{(\text {Mateo et al. 2003) }} \\
\mathbf{C d}^{(\text {García-Fernández et al. 1995, }} \\
\text { 1996) } \\
\mathbf{P b}^{\text {(Garć́a-Fernández et al. 1995, }} \\
\text { 1997; Mateo et al. 2003) } \\
(\mathrm{n}=120)\end{array}$ & $\begin{array}{l}\text { Cd } \mathbf{d}^{\text {(Martínez-López et al. 2005; }} \\
\text { Castro et al. 2011) } \\
\mathbf{H g}^{\text {(Castro et al. 2011; Martinez }} \\
\text { et al. 2012) } \\
\text { Pb }^{\text {(Martinez-López et al. 2004; }} \\
\text { Castro et al. 2011) } \\
(\mathrm{n}=56)\end{array}$ & $\begin{array}{l}\mathbf{C} \mathbf{d}^{\text {(Hernández et al. 1988b) }} \\
\mathbf{C u}^{\text {(Hernández et al. 1988b) }} \\
\mathbf{H g}^{\text {(Hernández et al. 1988b) }} \\
\mathbf{P b}^{\text {(Hernández et al. 1988b) }} \\
\mathbf{Z n}^{\text {(Hernández et al. 1988b) }} \\
(\mathrm{n}=4)\end{array}$ \\
\hline $\begin{array}{l}\text { Short-toed } \\
\text { eagle }\end{array}$ & $\begin{array}{l}\text { Cd }{ }^{(\text {Garciá-Fernández et al. 1996) }} \\
(\mathrm{n}=2)\end{array}$ & $\begin{array}{l}\text { Cd } \\
(\mathrm{n}=3)\end{array}$ & $\begin{array}{l}\text { Cd }{ }^{(\text {García-Fernández et al. 1996) }} \\
(\mathrm{n}=3)\end{array}$ & $\begin{array}{l}\text { Cd }{ }^{(\text {García-Fernández et al. 1996) }} \\
(\mathrm{n}=3)\end{array}$ & $\begin{array}{l}\text { Cd }{ }^{(\text {García-Fernández et al. 1996) }} \\
(\mathrm{n}=2)\end{array}$ & & \\
\hline $\begin{array}{l}\text { Marsh } \\
\text { harrier }\end{array}$ & $\begin{array}{l}\mathbf{H g}^{\text {(Alvárez et al. 2013) }} \\
\mathbf{P b}^{\text {(Mateo et al. 1999) }} \\
\mathbf{S e}^{\text {(Alvárez et al. 2013) }} \\
(\mathrm{n}=52)\end{array}$ & & & & & & $\begin{array}{l}\mathbf{C} \mathbf{d}^{\text {(Hernández et al. 1986) }} \\
\mathbf{C} \mathbf{u}^{\text {(Hernández et al. 1986) }} \\
\mathbf{H g}{ }^{\text {(Hernández et al. 1986) }} \\
\mathbf{P b}^{\text {(Hernández et al. 1986) }} \\
\mathbf{Z n} \text { (Hernández et al. 1986) } \\
(\mathrm{n}=17)\end{array}$ \\
\hline
\end{tabular}

1120

1121 
1122 Table 3. (Continued) The metals and metalloids measured in each raptor species from Portugal and Spain per sample type and the total number

1123 (n) of the different samples analysed for each species.

\begin{tabular}{|c|c|c|c|c|c|c|}
\hline & Blood $(n=2087)$ & Liver $(n=594)$ & Kidney $(n=318)$ & Brain $(n=193)$ & Bone $(n=593)$ & Feathers $(n=884)$ \\
\hline $\begin{array}{l}\text { Montagu's } \\
\text { harrier }\end{array}$ & $\begin{array}{l}\text { Cd } \\
(\mathrm{n}=1)\end{array}$ & $\begin{array}{l}\text { As } \mathbf{s}^{\text {(Hermoso de Mendoza et al. }} \\
\mathbf{C d}^{\text {(García-Fernández et al. 1996; }} \\
\text { Hermoso de Mendoza et al. 2006) } \\
\text { Pb }^{\text {(Hermoso de Mendoza et al. }} \\
2006) \\
\mathbf{Z n}^{\text {(Hermoso de Mendoza et al. }} \\
2006) \\
(\mathrm{n}=9)\end{array}$ & $\begin{array}{l}\text { Cd } \mathbf{d}^{(\text {García-Fernández et al. 1996) }} \\
(\mathrm{n}=1)\end{array}$ & $\begin{array}{l}\text { Cd } \mathbf{d}^{(\text {García-Fernández et al. 1996) }} \\
(\mathrm{n}=1)\end{array}$ & $\begin{array}{l}\mathbf{C d}^{(\text {García-Fernández et al. 1996) }} \\
(\mathrm{n}=1)\end{array}$ & \\
\hline $\begin{array}{l}\text { Bearded } \\
\text { vulture }\end{array}$ & $\begin{array}{l}\mathbf{P b}^{(\text {Hernández and Margalida 2009; }} \\
\text { Mateo et al. 2015) } \\
(\mathrm{n}=101)\end{array}$ & $\begin{array}{l}\text { Pb } \\
\text { 2009; Mateo et al. 2015) } \\
(\mathrm{n}=30)\end{array}$ & & & $\begin{array}{l}\mathbf{P b}^{(\text {Hernández and Margalida }} \\
\text { 2009; Mateo et al. 2015) } \\
(\mathrm{n}=43)\end{array}$ & \\
\hline $\begin{array}{l}\text { Griffon } \\
\text { vulture }\end{array}$ & 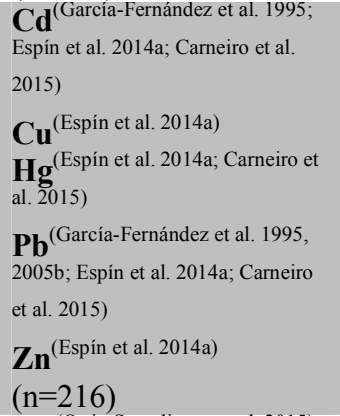 & 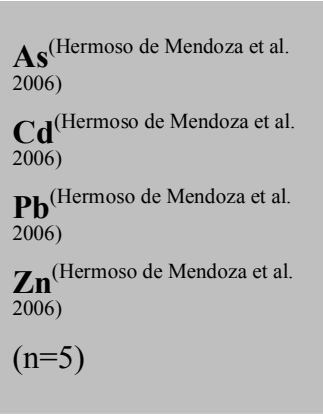 & & & $\begin{array}{l}\mathbf{A s}^{(\text {Mateo et al. 2003) }} \\
\mathbf{P b}^{\text {(Mateo et al. 2003; Cardiel et }} \\
\text { al. 2011) } \\
(n=24)\end{array}$ & $\begin{array}{l}\mathbf{A l}^{(\text {Cardiel et al. 2011) }} \\
\mathbf{P b}^{(\text {Cardiel et al. 2011) }} \\
(\mathrm{n}=20)\end{array}$ \\
\hline $\begin{array}{l}\text { Bonelli's } \\
\text { eagle }\end{array}$ & 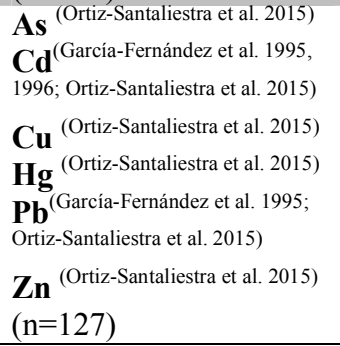 & & & & $\begin{array}{l}\mathbf{A s}^{(\text {Mateo et al. 2003) }} \\
\mathbf{P b}^{(\text {Mateo et al. 2003) }} \\
(\mathrm{n}=6)\end{array}$ & $\begin{array}{l}\mathbf{H g}^{\text {(Palma et al. 2005; Figueira et }} \\
\text { al. 2009) } \\
(\mathrm{n}=21)\end{array}$ \\
\hline
\end{tabular}


1125 Table 3. (Continued) The metals and metalloids measured in each raptor species from Portugal and Spain per sample type and the total number 1126 (n) of the different samples analysed for each species.

\begin{tabular}{|c|c|c|c|c|c|c|c|}
\hline & Blood $(n=2087)$ & Liver $(n=594)$ & Kidney $(n=318)$ & Brain $(n=193)$ & Bone $(n=593)$ & Feathers $(n=884)$ & Eggs $(n=268)$ \\
\hline Booted eagle & 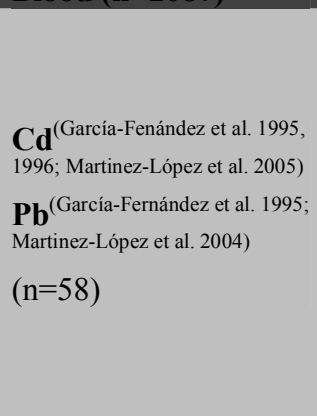 & $\begin{array}{l}\text { Cd } \text { (García-Fernández et al. 1995, }_{1996)} \\
\text { Pb }^{(\text {García-Fernández et al. 1995) }} \\
(\mathrm{n}=8)\end{array}$ & $\begin{array}{l}\text { Cd }^{\text {(García-Fernández et al. 1995, }} \\
\text { Pba6) }^{\text {(García-Fernández et al. 1995) }} \\
(\mathrm{n}=7)\end{array}$ & $\begin{array}{l}\text { Cd } \mathbf{d}^{(\text {García-Fernández et al. 1995, }} \\
\mathbf{P b}^{(\text {García-Fernández et al. 1995) }} \\
(\mathrm{n}=7)\end{array}$ & $\begin{array}{l}\mathbf{A s} \mathbf{s}^{(\text {Mateo et al. 2003) }} \\
\mathbf{C d}^{\text {(García-Fernández et al. 1996) }} \\
\mathbf{P b}^{\text {(Mateo et al. 2003) }} \\
(\mathrm{n}=17)\end{array}$ & $\begin{array}{l}\mathbf{C} \mathbf{d}^{\text {(Martinez-López et al. 2005) }} \\
\mathbf{P b}^{\text {(Martínez-López et al. 2004) }} \\
(\mathrm{n}=60)\end{array}$ & 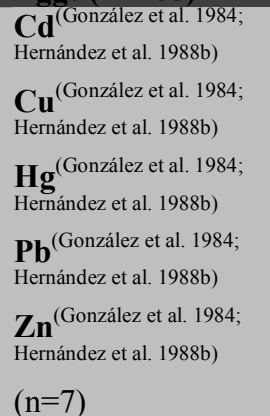 \\
\hline Black kite & 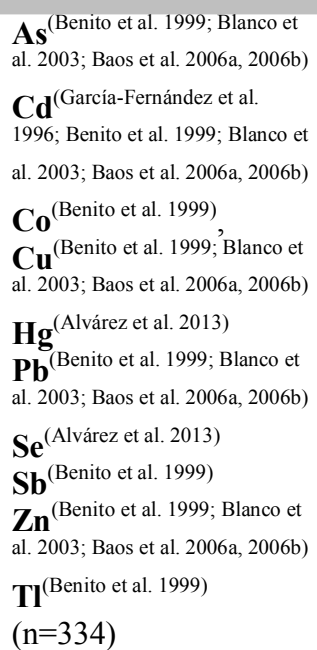 & $\begin{array}{l}\text { Cd } \mathbf{d}^{(\text {García-Fernández et al. 1996) }} \\
(\mathrm{n}=2)\end{array}$ & $\begin{array}{l}\text { Cd }{ }^{(\text {García-Fernández et al. 1996) }} \\
(\mathrm{n}=2)\end{array}$ & $\begin{array}{l}\text { Cd } \\
(\mathrm{n}=2)\end{array}$ & $\begin{array}{l}\mathbf{A s} \mathbf{s}^{\text {(Mateo et al. 2003) }} \\
\mathbf{C d}^{(\text {García-Fernández et al. 1996) }} \\
\text { Pb }^{\text {(Mateo et al. 2003; Cardiel et }} \\
\text { al. 2011) } \\
(\mathrm{n}=31)\end{array}$ & $\begin{array}{l}\mathbf{A l}^{(\text {Cardiel et al. 2011) }} \\
\mathbf{P b}^{(\text {Cardiel et al. 2011) }} \\
(\mathrm{n}=9)\end{array}$ & 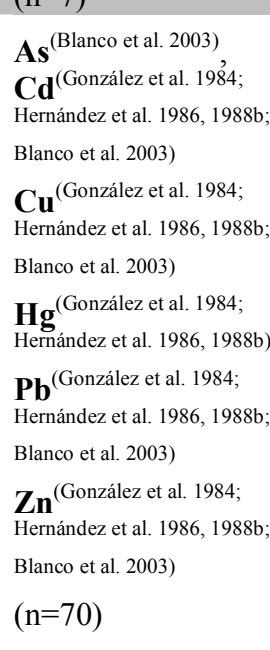 \\
\hline
\end{tabular}


1128 Table 3. (Continued) The metals and metalloids measured in each raptor species from Portugal and Spain per sample type and the total number

1129 (n) of the different samples analysed for each species.

\begin{tabular}{|c|c|c|c|c|c|c|}
\hline & Blood $(n=2087)$ & Liver $(n=594) \quad$ Kidney $(n=318)$ & Brain (n=193) & Bone $(n=593)$ & Feathers $(n=884)$ & Eggs $(n=268)$ \\
\hline Red Kite & & $\begin{array}{l}\text { As } \\
2006) \\
\mathbf{C d}^{(\text {Hermoso de Mendoza et al. }} \\
2006) \\
\mathbf{P b}^{\text {(Hermoso de Mendoza et al. }} \\
2006) \\
\mathbf{Z n}^{\text {(Hermoso de Mendoza et al. }} \\
2006) \\
(\mathrm{n}=5)\end{array}$ & & $\begin{array}{l}\mathbf{A s}^{(\text {Mateo et al. 2003) }} \\
\text { Pb }^{(\text {Mateo et al. 2003; Cardiel et }} \\
\text { al. 2011) } \\
(n=22)\end{array}$ & $\begin{array}{l}\mathbf{A l}^{(\text {Cardiel et al. 2011) }} \\
\mathbf{P b}^{(\text {Cardiel et al. 2011) }} \\
(\mathrm{n}=10)\end{array}$ & $\begin{array}{l}\mathbf{C d} \mathbf{d}^{\text {(González et al. 1984) }} \\
\mathbf{C u}^{\text {(González et al. 1984) }} \\
\mathbf{H g}{ }^{\text {(González et al. 1984) }} \\
\mathbf{P b} \mathbf{( G o n z a ́ l e z ~ e t ~ a l . ~ 1 9 8 4 ) ~}^{\text {(Gonźlez et al. 1984) }} \\
\mathbf{Z n}{ }^{\text {(González }} \\
(\mathrm{n}=10)\end{array}$ \\
\hline $\begin{array}{l}\text { Egyptian } \\
\text { vulture }\end{array}$ & $\begin{array}{l}\text { As }{ }^{(\text {Donázar et al. 2002) }} \\
\mathbf{C d}^{\text {(Donázar et al. 2002) }} \\
\text { Cu}^{\text {(Donázar et al. 2002) }} \\
\text { Pb }^{\text {(Donázar et al. 2002; Gangoso }} \\
\text { et al. 2009) } \\
\text { Zn } \\
\text { (nonázar et al. 2002) } \\
(\mathrm{n}=195)\end{array}$ & & & $\begin{array}{l}\mathbf{P b}^{(\text {Gangoso et al. 2009) }} \\
(n=39)\end{array}$ & & \\
\hline Lesser kestrel & & & & & & $\begin{array}{l}\mathbf{C d}^{\text {(Negro et al. 1993) }} \\
\mathbf{C u}^{\text {(Negro et al. 1993) }} \\
\mathbf{H g}^{\text {(Negro et al. 1993) }} \\
\mathbf{P b}^{\text {(Negro et al. 1993) }} \\
\mathbf{Z} \mathbf{n}^{\text {(Negro et al. 1993) }} \\
(\mathrm{n}=41)\end{array}$ \\
\hline Hobby & & & & & & $\begin{array}{l}\mathbf{C d} \mathbf{d}^{\text {(González et al. 1984) }} \\
\mathbf{C u}^{\text {(González et al. 1984) }} \\
\mathbf{H g}{ }^{\text {(González et al. 1984) }} \\
\mathbf{P b}^{\text {(González et al. 1984) }} \\
\mathbf{Z n}{ }^{(\text {González et al. 1984) }} \\
(\mathrm{n}=7)\end{array}$ \\
\hline
\end{tabular}


1131 Table 3. (Continued) The metals and metalloids measured in each raptor species from Portugal and Spain per sample type and the total number

1132 (n) of the different samples analysed for each species.

\begin{tabular}{|c|c|c|c|c|c|c|c|}
\hline & Blood $(n=2087)$ & Liver $(n=594)$ & Kidney $(n=318)$ & Brain $(n=193)$ & Bone $(n=593)$ & Feathers $(n=884)$ & Eggs $(n=268)$ \\
\hline $\begin{array}{l}\text { Peregrine } \\
\text { falcon }\end{array}$ & $\begin{array}{l}\mathbf{H g}^{\text {(Alvárez et al. 2013) }} \\
\text { Se }^{\text {(Alvárez et al. 2013) }} \\
(\mathrm{n}=6)\end{array}$ & & & & $\begin{array}{l}\mathbf{A s}^{\text {(Mateo et al. 2003) }} \\
\mathbf{P b}^{\text {(Mateo et al. 2003) }} \\
(\mathrm{n}=9)\end{array}$ & & $\begin{array}{l}\text { Cd } \text { (Hernández et al. 1988b) }^{\text {(Hernández et al. 1988b) }} \\
\mathbf{C u}{ }^{\text {(Hernández et al. 1988b) }} \\
\mathbf{H g} \\
\mathbf{P b} \text { (Hernández et al. 1988b) } \\
\mathbf{Z n}{ }^{\text {(Hernández et al. 1988b) }} \\
(\mathrm{n}=3)\end{array}$ \\
\hline $\begin{array}{l}\text { Common } \\
\text { kestrel }\end{array}$ & 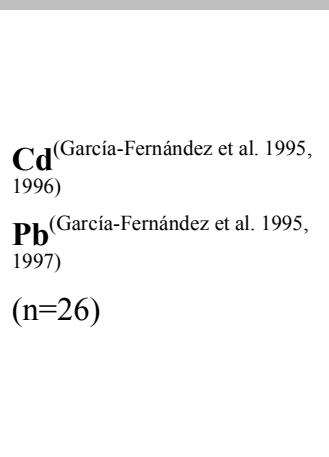 & 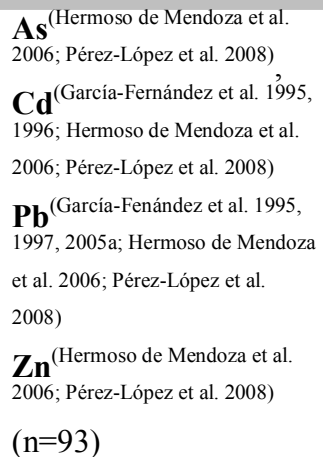 & 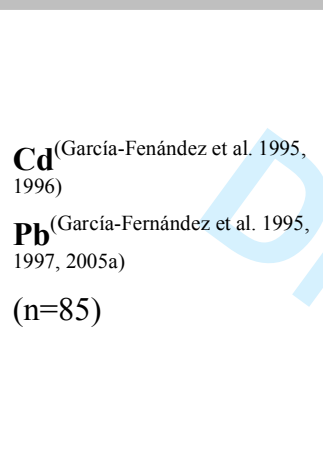 & $\begin{array}{l}\mathbf{C d}^{(\text {García-Fernández et al. 1995, }} \\
\text { 1996) } \\
\mathbf{P b}^{(\text {García-Fernández et al. 1995, }} \\
\text { 1997, 2005a) } \\
(\mathrm{n}=87)\end{array}$ & $\begin{array}{l}\text { Cd }{ }^{(\text {García-Fenández et al. 1995, }} \\
\text { 1996) } \\
\mathbf{P b}^{(\text {García-Fenández et al. 1995, }} \\
\text { 1997, 2005a) } \\
(\mathrm{n}=72)\end{array}$ & $\begin{array}{l}\mathbf{H g}^{(\text {Lourenço et al. 2011) }} \\
(\mathrm{n}=1)\end{array}$ & \\
\hline Little owl & $\begin{array}{l}\mathbf{C d} \mathbf{d}^{(\text {García-Fernández et al. 1995, }} \\
\text { Pb b }^{\text {(García-Fernández et al. 1995, }} \\
\text { 1997) } \\
(\mathrm{n}=11)\end{array}$ & 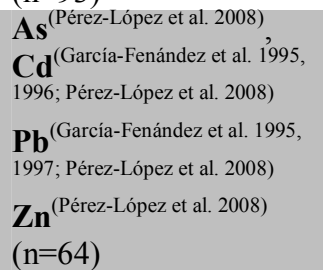 & $\begin{array}{l}\text { Cd }{ }^{(\text {García-Fernández et al. 1995, }} \\
\text { 1996) } \\
\text { Pb }^{\text {(García-Fernández et al. 1995, }} \\
\text { 1997) } \\
(\mathrm{n}=34)\end{array}$ & $\begin{array}{l}\mathbf{C} \mathbf{d}^{\text {(García-Fenández et al. 1995,. }} \\
\text { 1996) } \\
\mathbf{P b}^{(\text {García-Fenández et al. 1995, }} \\
\text { 1997) } \\
(\mathrm{n}=34)\end{array}$ & $\begin{array}{l}\text { Cd } \mathbf{d}^{\text {(García-Fenández et al. 1995, }} \\
\text { 1996) } \\
\mathbf{P b}^{(\text {García-Fenández et al. 1995, }} \\
\text { 1997) } \\
(\mathrm{n}=19)\end{array}$ & $\begin{array}{l}\mathbf{H g}^{(\text {Lourenço et al. 2011) }} \\
(\mathrm{n}=15)\end{array}$ & \\
\hline $\begin{array}{l}\text { Long-eared } \\
\text { owl }\end{array}$ & & $\begin{array}{l}\text { Às }{ }^{\text {(Pérez-López et al. 2008) }} \\
\mathbf{C d}^{\text {(García-Fernández et al. 1996; }} \\
\text { Pérez-López et al. 2008) } \\
\mathbf{P b}^{\text {(Pérez-López et al. 2008) }} \\
\mathbf{Z n}^{(\text {Pérez-López et al. 2008) }} \\
(\mathrm{n}=6)\end{array}$ & $\begin{array}{l}\text { Cd }^{(\text {García-Fernández et al. 1996) }} \\
(\mathrm{n}=1)\end{array}$ & $\begin{array}{l}\mathbf{C d}_{(\mathrm{n}=1)}^{(\text {García-Fenández et al. 1996) }} \\
(\mathrm{n}=1)\end{array}$ & $\begin{array}{l}\text { Cd } \\
(\mathrm{n}=1)\end{array}$ & & \\
\hline
\end{tabular}


1134 Table 3. (Continued) The metals and metalloids measured in each raptor species from Portugal and Spain per sample type and the total number

1135 (n) of the different samples analysed for each species.

\begin{tabular}{|c|c|c|c|c|c|c|c|}
\hline & Blood $(n=2087)$ & Liver $(n=594)$ & Kidney $(n=318)$ & Brain $(n=193)$ & Bone $(n=593)$ & Feathers $(n=884)$ & Eggs $(n=268)$ \\
\hline Eagle Owl & $\begin{array}{l}\mathbf{C d}^{\text {(Garcia-Fenández et al. 1995, }} \\
\text { 1996; Espín et al. 2014b) } \\
\mathbf{C u}^{\text {(Espin et al. 2014b) }} \\
\mathbf{H g}^{\text {(Espín et al. 2014b, 2014c) }} \\
\mathbf{P b}^{\text {(García-Fenández et al. 1995, }} \\
\text { 1997; Gómez-Ramírzz et al. 2010; } \\
\text { Espín et al. 2014b) } \\
\mathbf{Z n}^{\text {(Espín et al. 2014b) }} \\
\text { (n=834) }\end{array}$ & $\begin{array}{l}\mathbf{C} \mathbf{d}^{\text {(García-Fenández et al. 1995, }} \\
\mathbf{P b}^{\text {(García-Fenández et al. 1995, }} \\
{ }_{1997)} \\
(\mathrm{n}=26)\end{array}$ & $\begin{array}{l}\mathbf{C} \mathbf{d}^{\text {(García-Fenández et al. 1995, }} \\
\mathbf{P b}^{\text {(García-Fenández et al. 1995, }} \\
1997) \\
(\mathrm{n}=26)\end{array}$ & $\begin{array}{l}\mathbf{C} \mathbf{d}^{\text {(García-Fenández et al. 1995, }} \\
\text { 1996) } \\
\mathbf{P b}^{(\text {García-Fenández et al. 1995, }} \\
\text { 1997) } \\
(\mathrm{n}=26)\end{array}$ & 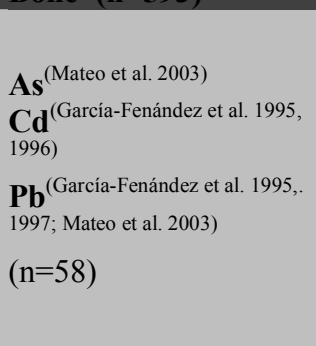 & $\begin{array}{l}\mathbf{H g}_{\text {et al. } 2011 ; \text { Espin et al. 2014c) }}^{(\text {Ortego et al. 2006; Lourenco }} \\
(\mathrm{n}=322)\end{array}$ & \\
\hline Scops Owl & & $\begin{array}{l}\text { Cd } \mathbf{d}^{\text {(García-Fenández et al. 1996) }} \\
(\mathrm{n}=1)\end{array}$ & $\begin{array}{l}\text { Cd } \mathbf{d}^{\text {(García-Fenández et al. 1996) }} \\
(\mathrm{n}=1)\end{array}$ & $\begin{array}{l}\text { Cd } \\
(\mathrm{n}=1)\end{array}$ & $\begin{array}{l}\text { Cd } \\
(\mathrm{n}=1)\end{array}$ & & \\
\hline Tawny Owl & & $\begin{array}{l}\mathbf{A s}{ }^{\text {(Pérez-López et al. 2008) }} \\
\mathbf{C d}^{\text {(Pérez-López et al. 2008; }} \\
\text { Castro et al. 2011) } \\
\mathbf{H g}^{\text {(Castro et al. 2011) }} \\
\text { Pb }^{\text {(Pérez-López et al. 2008; }} \\
\text { Castro et al. 2011) } \\
\mathbf{Z n}^{\text {(Pérez-López et al. 2008) }} \\
(\mathrm{n}=51)\end{array}$ & $\begin{array}{l}\mathbf{C d}^{\text {(Castro et al. 2011) }} \\
\mathbf{H g}^{\text {(Castro et al. 2011) }} \\
\mathbf{P b}^{\text {(Castro et al. 2011) }} \\
(\mathrm{n}=34)\end{array}$ & & & $\begin{array}{l}\mathbf{C d}^{\text {(Castro et al. 2011) }} \\
\mathbf{H g}^{\text {(Castro et al. 2011; Lourenço }} \\
\text { et al. 2011) } \\
\mathbf{P b}^{\text {(Castro et al. 2011; Debén et }} \\
\text { al. 2012) } \\
(\mathrm{n}=54)\end{array}$ & \\
\hline Barn owl & $\begin{array}{l}\mathbf{C d}^{(\text {García-Fenández et al. 1996) }} \\
(\mathrm{n}=1)\end{array}$ & 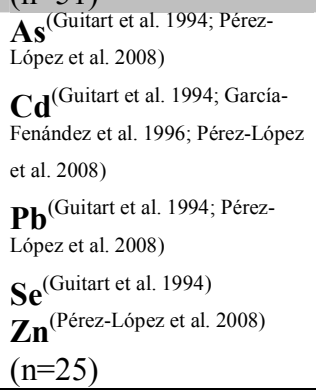 & $\begin{array}{l}\mathbf{C d}^{(\text {García-Fenández et al. 1996) }} \\
(\mathrm{n}=4)\end{array}$ & $\begin{array}{l}\text { Cd } \\
(\mathrm{n}=4)\end{array}$ & $\begin{array}{l}\mathbf{C d}^{(\text {García-Fenández et al. 1996) }} \\
(\mathrm{n}=3)\end{array}$ & $\begin{array}{l}\mathbf{H g}^{(\text {Lourenço et al. 2011) }} \\
(\mathrm{n}=13)\end{array}$ & \\
\hline
\end{tabular}


1138 Table 4. Analytical techniques used in the determination of metals in biological samples of

1139 the raptors from Portugal and Spain.

\begin{tabular}{|c|c|}
\hline Analytical technique & Elements \\
\hline $\begin{array}{l}\text { Atomic Absorption Spectrometry } \\
\text { (AAS) }\end{array}$ & \\
\hline - Flame & 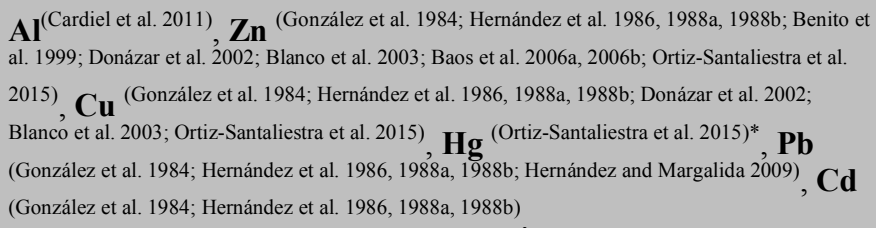 \\
\hline - Graphite furnace & 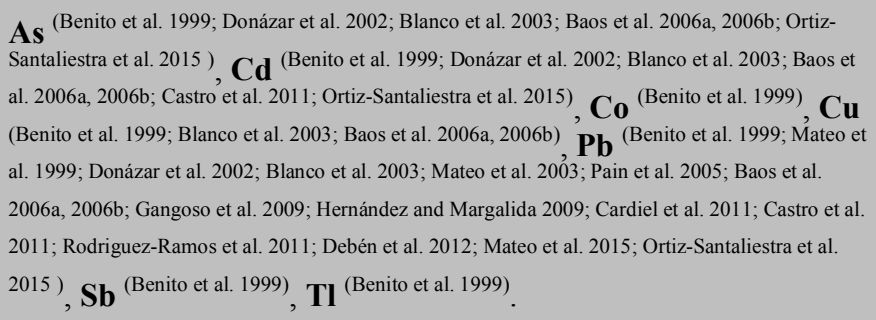 \\
\hline - Hydride generation & As ${ }^{\text {(Mateo et al. 2003) }}$ \\
\hline - Cold vapour & $\begin{array}{l}\text { Hg (González et al. 1984; Hernández et al. 1986; Palma et al. 2005; Ortego et al. 2006; Figueira et } \\
\text { al. 2009; Castro et al. 2011; Lourenço et al. 2011; Martínez et al. 2012; Alvárez et al. 2013; Espín et } \\
\text { al. 2014a, 2014b, 2014c) }\end{array}$ \\
\hline
\end{tabular}

Inductively Coupled Plasma (ICP)

- Atomic/Optical Emission

Pb (Mateo et al. 1999; Gangoso et al. 2009). Spectrometry (AES)/(OES)

- $\quad$ Mass Spectrometry (MS)

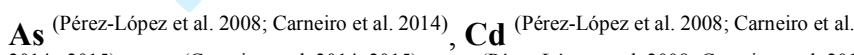

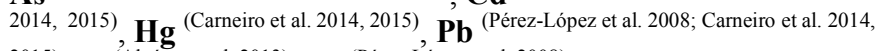

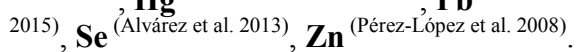

\begin{tabular}{|c|c|}
\hline Anodic Stripping Voltammetry (ASV) & 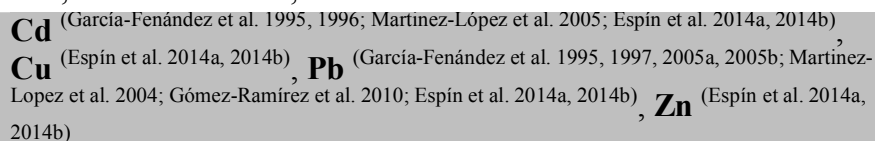 \\
\hline
\end{tabular}

* Mercury/Hibrid system coupled to the AAS 
1142 Table 5.1. Range of mean concentrations of the studied metals and metalloids in blood, liver and kidney samples of the studied raptors species

1143 from the Iberian Peninsula.

0.8 (Black kite) ${ }^{(\text {Benito et al. 1999) }}$

26.24 (Black kite) ${ }^{(\text {Baos et al. 2006b) }}$

n.d. (Griffon vulture, Bonelli's eagle) ${ }^{(\text {Carneiro et al. 2015; Ortiz- }}$

Santaliestra

0.68 (Black kite) ${ }^{(\text {Benito et al. 1999) }}$

n.d. (Griffon vulture) ${ }^{(\text {Carneiro et al. 2015) }}$

20. 94 (Common buzzard) (Carneiro et al. 2014)

56.7* (Peregrine falcon) ${ }^{\text {(Alvárez et al. 2013) }}$

2.45*(Bearded vulture $)^{\text {(Hernandez and Margalida 2009) }}$

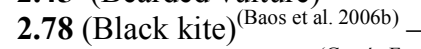

43.07 (Griffon vulture) ${ }^{(\text {García-Fenández et al. 2005b) }}$

n.d. (Bonelli's eagle) ${ }^{\text {(Ortiz-Santaliestra et al. 2015) }}$

36.86 (Black kite) ${ }^{(B a o s ~ e t ~ a l . ~ 2006 b) ~}$

330 (Black kite) $^{(\text {Benito et al. 1999) }}$

528 (Black kite) $^{(\text {Baos et al. 2006b) }}$

53,8*, 43,9* (Peregrine falcon) ${ }^{\text {(Alvárez et al. 2013) }}$

Not measured

Not measured

$\mathbf{0 . 1 0}$ (Common buzzard) (Carneiro et al. 2014)

$\mathbf{6 . 8 8}$ (Tawny Owl) ${ }^{(\text {Pérez-López et al. 2008) }}$

0.05 (Booted eagle) ${ }^{(\text {García-Fenández et al. 1995) }}$

$\mathbf{5 . 5 2}$ (Tawny Owl) ${ }^{(\text {Pérez-López et al. 2008) }}$

1.39 (Common buzzard) ${ }^{(\text {Carneiro et al. 2014) }}$

0.39 (Common buzzard) (García-Fenández et al. 1995)

6.64 (Common kestrel) ${ }^{\text {(Pérez-López et al. 2008) }}$

Not measured

134.24 (Griffon vulture) ${ }^{\text {(Hermoso de Mendoza et al. 2006) }}$ 360.3 (Tawny Owl) $^{\text {(Pérez-López et al. 2008) }}$

Not measured
0.18 (Common buzzard) ${ }^{(\text {Carneiro et al. 2014) }}$

0.13 (Booted eagle) ${ }^{(\text {García-Fenández et al. 1995) }}$ 1.81 (Common kestrel) ${ }^{(\text {García-Fenández et al. 1995) }}$

2.09 (Common buzzard) ${ }^{(\text {Carneiro et al. 2014) }}$

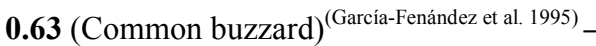

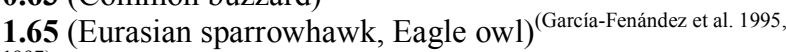

Not measured

Not measured

Not measured

Not measured 
1146 Table 5.2 Range of mean concentrations of the studied metals and metalloids in brain, bone, feathers and eggs samples of the studied raptors

1147 from the Iberian Peninsula.

\begin{tabular}{|c|c|c|c|c|}
\hline & Brain ( $\mu$ g/g w.w.) & Bone ( $\mu \mathrm{g} / \mathrm{g} \mathrm{d.w.)}$ & Feathers ( $\mu \mathrm{g} / \mathrm{g}$ d.w.) & Eggs ( $\mu$ g/g w.w.) \\
\hline As & Not measured & $\dagger$ & Not measured & $\begin{array}{l}\text { 0.01 (Black kite) })^{(\text {Blanco et al. 2003) }}- \\
\mathbf{0 . 0 2} \text { (Black kite) }{ }^{(\text {Blanco et al. 2003) }}\end{array}$ \\
\hline Cd & 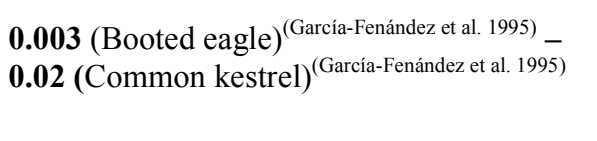 & 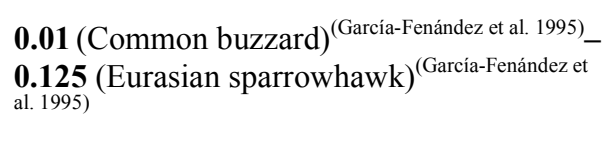 & $\begin{array}{l}\mathbf{0 . 0 2} \text { (Northern goshawk, Booted } \\
\text { eagle) }{ }^{\text {(Martinez-López et al. 2005) }}- \\
\mathbf{0 . 0 3} \text { (Common buzzard) }\end{array}$ & $\begin{array}{l}\mathbf{0 . 0 0 6} \text { (Black kite) }^{(\text {Blanco et al. 2003) }}- \\
\mathbf{0 . 1 8} \text { (Black kite) }{ }^{(\text {González et al. 1984) }}\end{array}$ \\
\hline Hg & Not measured & Not measured & 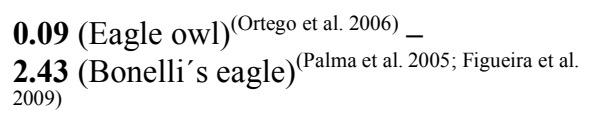 & $\begin{array}{l}\mathbf{0 . 0 3} *(\text { Black kite })^{\text {Hernandez et al. } 1988}, \mathbf{0 . 1 9} \\
(\text { Booted eagle })- \\
\mathbf{0 . 4 5} \text { (Black kite) })^{(\text {González et al. 1984) }}\end{array}$ \\
\hline$\underline{\mathrm{Pb}}$ & $\begin{array}{l}\text { 0.02(Common buzzard })^{(\text {García-Fenández et al. 1995, }} \\
\text { 1997) _ } \\
\mathbf{0 . 1 4} \text { (Common buzzard) }{ }^{(\text {García-Fenández et al. 1995) }}\end{array}$ & $\begin{array}{l}\text { 0.46 }(\text { Bearded vulture })^{(\text {Mateo et al. 2015) }}-\mathbf{4 6 . 3 5} \\
(\text { Eagle owl })^{(\text {García-Fernández et al. 1995) }}\end{array}$ & $\begin{array}{l}\mathbf{0 . 0 3 3} \text { (Spanish Imperial eagle })^{(\text {Rodriguez-Ramos et }} \\
\text { al. 2011)}-\mathbf{1 . 0 1} \text { (Common buzzard })^{(\text {Martinez-Lopez et }} \\
\text { al. 2004) }\end{array}$ & 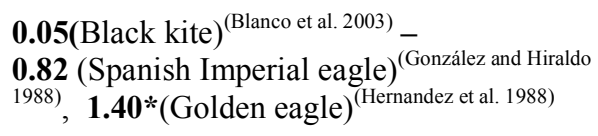 \\
\hline $\mathrm{Cu}$ & Not measured & Not measured & Not measured & $\begin{array}{l}\text { 0.65 (Black kite) })^{(\text {Blanco et al. 2003) }} \text { - } \\
\text { 2.07 } \text { (Hobby) }^{(\text {González et al. 1984) }}\end{array}$ \\
\hline Zn & Not measured & Not measured & Not measured & $\begin{array}{l}\text { 10.2 (Spanish Imperial eagle) - } \\
\mathbf{1 4 . 7 9} \text { (Black kite) })^{(\text {González et al. 1984) }}\end{array}$ \\
\hline Se & Not measured & Not measured & Not measured & Not measured \\
\hline Al & Not measured & Not measured & $\begin{array}{l}\text { n.d. in the rachis (Griffon vulture, Cinereous } \\
\text { vulture, Black kite, Red kite) }{ }^{\text {(Cardiel et al. 2011) }}- \\
\mathbf{1 1 4 4} \text { in the barbs (Griffon vulture) } \\
\text { 2011) }\end{array}$ & Not measured \\
\hline
\end{tabular}


https://mc06.manuscriptcentral.com/er-pubs 